Article

\title{
Free and open-source software for Geographic Information System on coastal management: a study case of sea-level rise in southern Brazil
}

\author{
Lucas T. de Lima 1,*, Sandra Fernández-Fernández ${ }^{2}$, Carlos V. C. Weiss ${ }^{3}$, Volney Bitencourt ${ }^{4}$, and Cristina Bernardes
} 1

1 CESAM - Centre for Environmental and Marine Studies, Department of Geoscience, University of Aveiro, 3810-193 Aveiro, Portugal; cbernardes@ua.pt

2 CESAM - Centre for Environmental and Marine Studies, Department of Physics, University of Aveiro, 3810-193 Aveiro, Portugal; sandrafernandez@ua.pt

3 IH Cantabria - Instituto de Hidráulica Ambiental de la Universidad de Cantabria, Santander - Spain; c.vinicius@msn.com

4 Researcher and Consultant in Geosciences, volneybitencourt@gmail.com

* Correspondence: lucasterres@ua.pt

\begin{abstract}
This work assesses sea-level rise using three different models created on Free and Open-Source Software for Geographic Information System (FOSS4GIS). Based on regional projections of Special Report on Climate Change and Oceans and Cryosphere (SROCC) of the Intergovernmental Panel on Climate Change (IPCC), the models were applied to a case of study on Rio Grande do Sul coast - Brazil under different sea-level rise scenarios by the end of this century. The End Point Rate for QGIS (EPR4Q), calculates a shoreline projection using End Point Rate method. The Uncertainty Bathtub Model (uBTM), analyses the sea-level rise impact by the uncertainty of sea-level projections and vertical error of the Digital Elevation/Terrain Model (DEM/DTM). The Bruun Rule for Google Earth Engine Model (BRGM) predicts the shoreline position with sea-level rise, using topographic and bathymetric data from Unmanned Aerial Vehicles (UAV) and Coastal Modelling System (SMC - Brazil), respectively. The results indicated a maximum shoreline retreat for 2100 of $-502 \mathrm{~m}$ and $-1727 \mathrm{~m}$ using EPR4Q and BRGM, correspondingly. The uBTM using the land-use of Mapbiomas showed a maximum of $44.57 \mathrm{~km}^{2}$ of urban area impacted by the sea-level flood. This research highlights the possibility of performing coastal management analysis in GIS environment using non-commercial software.
\end{abstract}

Keywords: Climate Change; Modeling; Coastal Hazards; End Point Rate; Uncertainty Bathtub; Bruun Rule

\section{Introduction}

It is undeniable that most coastal areas of the planet are currently impacted by Sea-Level Rise (SLR) [1,2]. The average rate of SLR observed by tide gauges in the 20th century was $1.7 \mathrm{~mm} \cdot \mathrm{yr}^{-1}$ [3], and the average altimeter level from 1993 to 2016 was 3.3 mm.yr-1 $[4]$.

Moreover, [5] estimates that more than 600 million people live in low-altitude coastal areas, and the number may increase to more than 1 billion by 2060 . Future sea-level rise as a result of global warming can seriously threat the human activities in these regions, and the consequences of the climate change will continue even if the emissions of greenhouse gases decrease significantly [6]. It is well known that the SLR will increase coastal erosion along worldwide coasts [7-13]. However, in contrast to this general trend, the morphodynamics and sediment supply responses (shoreline adjustment) to new sea-level conditions will vary significantly among different coastal stretches [14]. 
The last report of the Intergovernmental Panel on Climate Change (IPCC) included several scenarios of regional sea-level changes, which make it possible to get a more precise analysis of SLR impacts at a local scale [15]. Besides, with the increase of areas affected by SLR worldwide, it is important that free and efficient alternative Geographic Information System (GIS) models and tools would be developed for diagnosis, monitoring, and management of the coastal zone. These models can help stakeholders in different scenarios and contexts of coastal morphodynamic trends.

\subsection{End Point Rate for QGIS (EPR4Q)}

One of the key analyses in coastal management is the study of shoreline trends. This study is essential to understand the changes in behavior and predict the position of the shoreline in the near future. The End Point Rate for QGIS (EPR4Q) is a tool created for QGIS 3.4 that performs the End Point Rate (EPR) method [16]. The EPR is one of several techniques of shoreline trend analyses (i.e., Linear Regression Rate, Shoreline Change Envelope, Net Shoreline Movement, Weighted Linear Regression) [17]. The advantage of the EPR is to predict future positions with just two shorelines, being a powerful tool to get a first impression of the impacts of SLR in a specific study area.

\subsection{Uncertainty Bathtub Model (uBTM)}

The Uncertainty Bathtub Model is a method based on the Bathtub Model (BTM) and Terrset Sea-level impact, which reveals the probability of an area to be flooded, determining a specified elevation as a single value of water surface or bathtub [18]. In this case, the Uncertainty Bathtub Model is a BTM classified by the uncertainty of sea-level projections and the vertical error of the Digital Terrain Model (DTM) to predict the sea-level flood in the future [19]. Modifications of BTM as those proposed by [20] and [21] are examples of similar models for GIS environment.

\subsection{Bruun Rule for Google Earth Engine Model (BRGM)}

The Bruun Rule for Google Earth Engine Model is a tool created on this platform that performs the Bruun Rule equation [19]. The equation [22] uses the berm height and the depth of closure (DoC) as a physical variable to calculate the sea-level rise. The berm height is defined by a horizontal plateau on the beach face or backshore, and the depth of closure is an empirical measurement of the seaward limit of significant cross-shore sediment transport on sandy beaches [23]. Subsequently, [24] proposed a formulation using extreme wave conditions to obtain the value of DoC. The Bruun Rule is a controversial physical formula and requires precaution to be applied due to its simplicity. The equation does not contemplate the sediment supply, is two-dimensional and only considers one value of SLR [25]. Besides, the method allows to have a preliminary analysis, taking into account that sandy beach volume in a wave-dominated regime is mainly constant (e.g., Rio Grande do Sul - Brazil Coastal Plain (RSCP) beaches [26]) and shows $70 \%$ of similarity of the shoreline retreat predictions in laboratory-scale experiments [27].

This paper aims to analyze the shoreline position in 2100 as well as to evaluate the areas of littoral flood in the Rio Grande do Sul coastal plain, southern Brazil. The analysis is based on the application of three informatic tools considering two of the scenarios included in the last IPCC report: Representative Concentration Pathway (RCP) 4.5, and RCP 8.5. It is intended that the application of the models can provide different perspectives for analyzing the impact of sea level rise and support future decision making in the region under analysis.

\subsection{Study Area}

The Rio Grande do Sul State coastal plain (RSCP), located in southern Brazil, has thirty-two municipalities bordering the $620 \mathrm{Km}$ shoreline of the Atlantic Ocean and three 
major coastal lagoons (Patos, Mangueira and Mirim) (Figure 1). The State has 5.4\% of the Brazilian population with a total of about three million people [28] and occupies the third position of the Gross Domestic Product (GPD) of all federative units [29]. Regarding the natural and cultural heritage, the Rio Grande do Sul coastal plain (RSCP) has important natural park -Taim, Lagoa do Peixe, Itapuã, Camaquã, Mato Grande and Delta of Jacuíwith a very important biodiversity [30] and being a crucial area for migration birds of all around the world [31]. The RSCP has four indigenous villages and several archaeological sites of firsts human occupations in the region, with more than five thousand years $[32,33]$. From an economic perspective, beyond the important harbor activities, agriculture, industry, and tourism [29], the mineral extractions are growing in RSCP and related to mineral resources as titanium, iron, copper, peat, coal among others [34] (Figure 1).

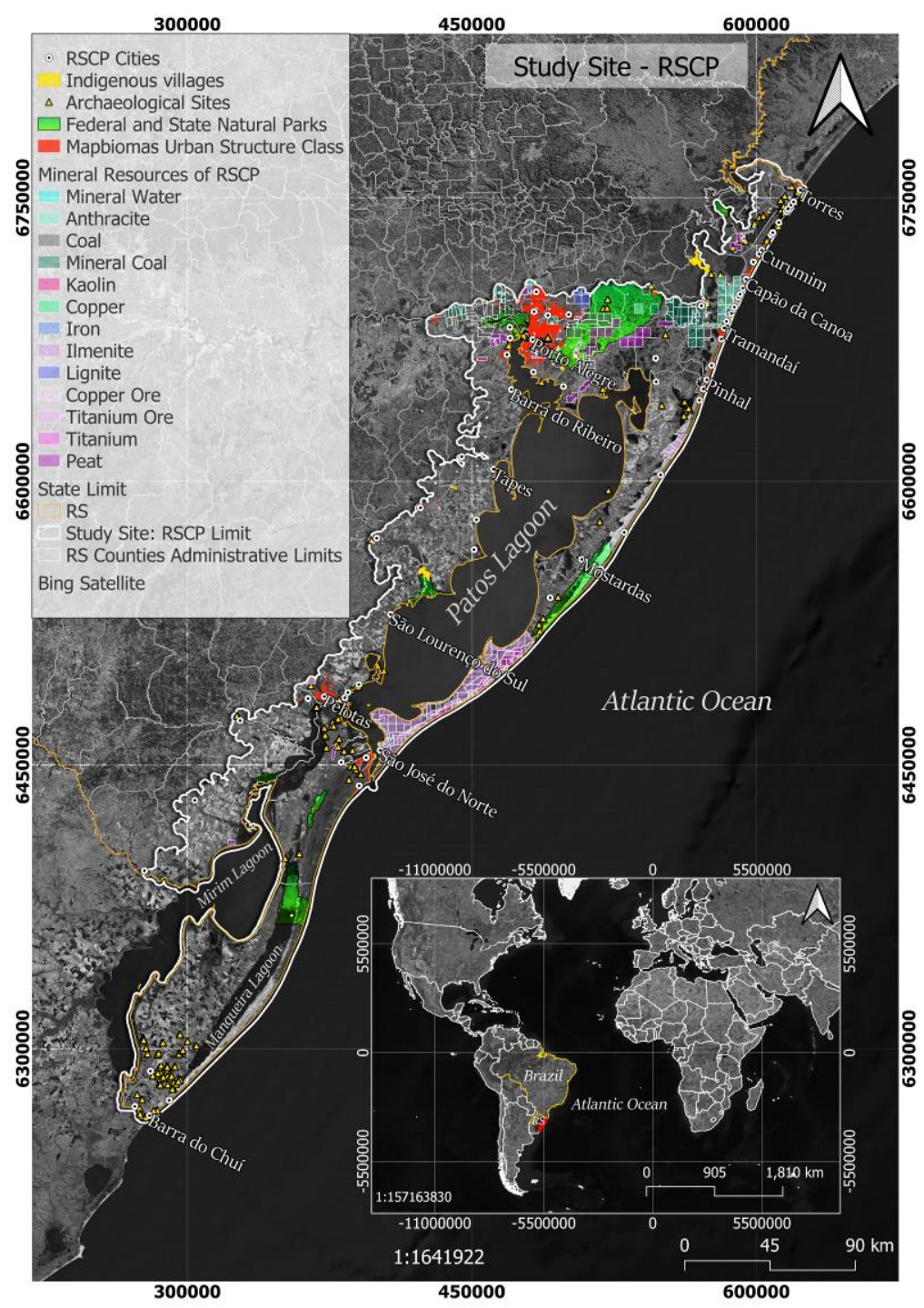

Figure 1. Study area with indication of historical (archeological sites), cultural (indigenous villages and cities), environmental (natural parks), and economic (mineral resources) (data source from [34-37]).

\subsubsection{Geological Setting}

The RSCP has the most uniform coastal plain of the country and also the widest extensive sandy barrier-lagoon system of South America [38] that includes the Patos Lagoon, which is considered one of the largest coastal lagoon in the world [39]. The lagoon has a length of about $250 \mathrm{~km}$, a maximum width of $40 \mathrm{~km}$, a surface area near $10200 \mathrm{~km}^{2}$, an average depth of $5 \mathrm{~m}$ and a drainage basin area greater than $200000 \mathrm{~km}^{2}[40,41]$. The system is connected to the Atlantic Ocean through a narrow channel, which is less than 1 
$\mathrm{km}$ wide and about $18 \mathrm{~m}$ mean deep. Nowadays, this channel is protected by two jetties (in the northeastern Cassino beach zone, and in the southwest São José do Norte) with a length of $1 \mathrm{~km}$ each (Figure 1).

The sandy barrier system, with approximately $33000 \mathrm{~km}^{2}$ and an average width of about $100 \mathrm{~km}$, corresponds to almost $9.5 \%$ of the whole RS area. Since the beginning of the Holocene, the barrier system shows the coexistence of different stratigraphical framework (stationary, regressive and transgressive tendencies) [38] in response to sea level fluctuations, sediment supply and coastal processes. Each type of barrier seems to have had different shoreline displacement trends in the long term ( $>10^{3}$ years) [41].

Nowadays, the beach system associated to the sandy barrier receives minimal sediment input from the continent. The beaches are constituted by well-sorted fine quartz sand and show dissipative to intermediate morphodynamic states [42]. The width is very variable, which in some cases can compromise the ability to moderate the impacts of adverse conditions, such as storms. Most of the sediment load carried by rivers that drain to the coast is trapped in the adjacent lagoons and associated environments [43]. The Patos Lagoon estuary is the largest exporter of fine-grain sediments to the inner and outer shelf regions [44].

\subsubsection{Oceanographic Setting}

The coast of RS is a typical wave-dominated environment with a combination of high and moderate wave energy and a low micro tide regime [38]. In the past, these characteristics, coupled with the abundance of sediment and the gentle slope of the continental shelf, have established perfect conditions for coastal barriers along the coast [38].

The tide is semidiurnal, with an average range of about $0.5 \mathrm{~m}$. Storm surges are frequent and can raise the water level by more than $1 \mathrm{~m}$ [45]. Based on a 30-year (1979 and 2008) deep-water wave modeling with the NOAA WAVEWATCH III®, the average wave directions are from south quadrant ( $51 \%$, the sum of annual occurrence), followed in order of importance by east quadrant ( $43 \%$, the sum of annual occurrence). South swell waves are more frequent in the autumn and winter seasons, while East quadrant waves are dominant in summer (ENE seas) and spring seasons (ENE swells). The waves exhibit an average significant wave height between 1 and $1.50 \mathrm{~m}$, with a peak wave period between 6 and $14 \mathrm{~s}$ [46]. Along the wave breaker line of the RS coast, there is a variation of more than $60 \%$ in the significant wave height [38]. Waves generated by powerful storms (extreme events) can reach up to $5 \mathrm{~m}$ in height. Such high wave energy conditions occur on average every 1-2 years in the RS $[47,48]$. However, most storms $(>80 \%)$ on the RS littoral generate waves with 2 to $3 \mathrm{~m}$ height [49]. The net longshore sediment transport is in the NE direction [50-52]. Based on the CERC (Coastal Engineering Research Center) formula, the net northward longshore transport is estimated from 0.60 to $2.93 \mathrm{Mm}^{3} \cdot \mathrm{yr}^{-1}$ along the RS coast [52,53].

\subsubsection{Climatic Setting}

According to Köppen climate classification system [54], the RS coast has a humid subtropical climate (Cfa), with hot summers (with an average of 21 to $24^{\circ} \mathrm{C}$ ) and cold winters (with an average of 12 to $14^{\circ} \mathrm{C}$ ), and well-distributed rainfall throughout the year $\left(\sim 1350\right.$ mm.year $\left.^{-1}\right)[55,56]$. The weather is mainly influenced by climate systems such as the South Atlantic Anticyclone (SAA), which produces the hot and humid air mass (Atlantic Tropical Mass - aTm) during the spring and summer months, and the Polar Migratory Anticyclone (PMA), which is responsible for the Atlantic Polar Mass (aPm), more frequent during the autumn and winter months [43]. The NE wind direction is predominant during the spring and summer. The W-SW wind direction is the second most frequent and is more constant in autumn and winter [57].

\section{Materials and Methods}


The analysis of the shoreline behavior in a sea-level rise scenario was performed using the Uncertainty Model for the oceanic and lagoon shorelines (Patos lagoon), while the EPR and the Bruun Rule methods were used only for the oceanic shoreline. Major cities were chosen for further analysis.

The predicted values of sea-level rise for the region for the period 2081-2100 according to the Special Report on the Ocean and Cryosphere in a Changing Climate (SROCC) [56] are: $0.46 \mathrm{~m}$ (0.31 - 0.63) under Representative Concentration Pathway (RCP) 4.5 and $0.68 \mathrm{~m}(0.50-0.90)$ under RCP 8.5. These values include Antarctica ice melt, glacio-isostatic adjustment (GIA), the gravitational and rotational effects, as well as the obtained results by [57] for glaciers, land water storage (LWS), and Greenland.

\subsection{End Point Rate (EPR4Q)}

Since the EPR only considers two shorelines in the prediction calculation, it was developed a method to select the best years from the period 1984-2016 of the differences of tidal flats data from [58]. The raster of tidal flats is a product that resulted from a global extent machine learning process of 700000 satellite images, which mapped the change in tidal flats over 33 years (1984-2016) [58]. The tidal flats data showed adequate to calculate the shoreline variation since the geological and oceanographic characteristics of Rio Grande do Sul coast, which shows sandy beaches and micro tides, allows quantifying the effect of sea-level rise using the tidal flats data.

The method created to apply in the tidal flats data allows identifying the years that showed an anomalous exchange of sediments that can influence the shoreline position. Also, the years with fewer changes in shorelines are adequate to be used in EPR. The tidal flats data were subtracted, and the difference was transformed into vector points. A heatmap was created to identify clusters with considerable changes and they were manually classified in a GIS environment (Table 1).

Table 1. Classification of tidal flats movement on RSCP.

\begin{tabular}{|c|c|c|}
\hline$\overline{\text { ID }}$ & Movement & Description \\
\hline$\overline{1}$ & Shoreline Retreat & Only retreat of the shoreline \\
\hline 2 & Shoreline Retreat & Retreat of shoreline plus increase in the difference of tidal flats \\
\hline 3 & Stationary & Stationary with increase in the difference of tidal flats \\
\hline 4 & Shoreline Advance & Only advance of shoreline \\
\hline 5 & Shoreline Advance & Advance of shoreline plus increase in the difference of tidal flats \\
\hline 6 & Shoreline Advance & Advance of shoreline plus decrease in the difference of tidal flats \\
\hline 7 & Shoreline Retreat & Retreat of shoreline plus decrease in the difference of tidal flats \\
\hline 8 & Stationary & Stationary with decrease in the difference of tidal flats \\
\hline
\end{tabular}

The results of shoreline shifting rates were founded on scale classification proposed by [12]: accretion $\left(>0.5 \mathrm{~m}\right.$. year- $\left.{ }^{-1}\right)$, stable $\left(-0.5 \mathrm{~m}\right.$. year- ${ }^{1}$ to $0.5 \mathrm{~m}$. year- $\left.{ }^{-1}\right)$, erosion $(-1.0 \mathrm{~m}$. year- ${ }^{-1}$ to $-0.5 \mathrm{~m}$. year- $\left.{ }^{-1}\right)$, intense erosion $\left(-3.0 \mathrm{~m}\right.$. year- ${ }^{1}$ to $-1.0 \mathrm{~m}$. year- $\left.{ }^{-1}\right)$, severe erosion $\left(-5.0 \mathrm{~m}\right.$. year- ${ }^{-1}$ to $-3.0 \mathrm{~m}$. year- $\left.{ }^{-1}\right)$, and extreme erosion $\left(<-5.0 \mathrm{~m}\right.$. year- $\left.{ }^{-1}\right)$.

\subsection{Uncertainty Bathtub Model (uBTM)}

The model was created on Google Earth Engine (GEE), a cloud-based platform that offers high-performance computing resources for processing geospatial datasets [59]. The model considers the uncertainly of the vertical accuracy of the DEM and the SLR projections [19]. The final output is a terrain image smoothed with a circle kernel filter classified from 0 to 100 percent, where places with pixels values of zero assumed by the model present zero percent of possibility to be impacted by the sea-level flood. The places with a hundred percent of possibility to be flooded have a pixel value of 100 .

Therefore, the model was applied in a Digital Terrain Model (DTM) from Digital Elevation Model (DEM) ALOS World 3D-30m (AW3D30) of Japan Aerospace Exploration Agency (JAXA) mission [59], with $30 \mathrm{~m}$ of spatial resolution and vertical accuracy of 4.1 
$\mathrm{m}$ [60]. The product was transformed to DTM using the modules for digital terrain model of QGIS software: filter tool and close gaps with stepwise resampling tool configured with the mean slope in the percentage of AW3D30 DEM that resulted on $1.40 \%$, calculated with the statistics for raster tool.

The methodology to evaluate the impact of sea-level flood using uBTM consists of extracting the urban infrastructure class of Land Use MapBiomas [37], transformed into polygons with raster to polygons tool, and applying the union tool with de UBTM result of RCP 4.5 and RCP 8.5. Subsequently, the areas were calculated in square meters and hectares that allow predicting the sea-level flood impact by the end of the century. The urban infrastructure class of Mapbiomas was manually segmented in QGIS 3.4 into twelve groups according to proximity, context, and area (Table 2) to improve the evaluation of the impacted area.

Table 2. Urban areas class segmented on twelve cities group.

\begin{tabular}{llll}
\hline ID & Name & Counties & Cities/Locations \\
\hline 1 & Littoral North Cities Group 1 & Torres and Arroio do Sal & Torres, Arroio Seco Beach, \\
& (LNCG 1) & & Praia da Riveira, Praia Santa \\
& & Helena, Praia Estrela do \\
& & Mar, Rondinha, Areias \\
& & Brancas, Arroio do Sal.
\end{tabular}

2 Littoral North Cities Group 2 Terra de Areia, Capão da Curumim, Arroio Teixeira, (LNCG 2) Canoa, Maquiné, Xangri-lá, Osório, Imbé, and Tramandaí.

Capão Novo, Capão Novo, Capão da Canoa, Osório, Capão Alto, Noiva do Mar, Rainha do Mar, Santa Terezinha, Albatroz, Mariluz, Imbé, Tramandaí, and Jardim do Edén.

$3 \quad$ Littoral North Cities Group 3 (LNCG 3)

Cidreira, Balneário Pinhal, and Capivari do Sul, Palmares do Sul.

Capivari do Sul, Cidreira, Palmares do Sul, Pinhal, Balneário Magistério, and Balneário Quintão Novo.

$4 \quad$ Mostardas

Mostardas and Tavares

São Simão, Mostardas, Balneário Mostardense, and Tapes.

5 São José do Norte

6 Rio Grande

7 Santa Vitória do Palmar (Chuí and HermenegildoP)

8 Metropolitan Area of Porto Alegre (MAPOA)

9 Tapes

10 Arambaré

11 São Lourenço do Sul (SLS)

12 Pelotas
São José do Norte

Rio Grande

Santa Vitória do Palmar and Chuí

Porto Alegre, Canoas, Cachoeirinha, Gravataí, São José do Norte, Praia do Mar Grosso, and Bujuru. Quinta, Rio Grande, and Cassino.

Santa Vitória do Palmar, Hermenegildo, Chuí, and Barra do Chuí.

Porto Alegre, Canoas, Cachoeirinha, Gravataí, Viamão, Nova Santa Rita, Viamão, Nova Santa Rita, Triunfo, El Dourado do Sul, Sans-Souci, Triunfo, El and Guaíba.

Dourado do Sul, and Guaíba.

Barra do Ribeiro Barra do Ribeiro and Tapes. and Tapes.

Arambaré and Santa Rita do Sul Arambaré and Santa Rita do Sul.

São Lourenço do Sul São Lourenço do Sul.

Pelotas, and Capão do Leão Pelotas, Laranjal, Balneário dos Prazeres, Colônia de Pescadores Z3, and Capão do Leão. 


\subsection{Bruun Rule for GEE Model (BRGM)}

The application of Bruun Rule was performed using the data extracted from field surveys with the Unmanned Aerial Vehicles (UAV) Phantom 4 Pro. The photogrammetric surveys performed in twelve beaches (Curumim, Albatroz, Tramandaí, Cidreira, Dunas Altas, Bujuru, Cassino, Saritas, Verga, Concheiros, Hermenegildo and Barra do Chuí) (Figure 2) show $2.5 \mathrm{~cm}$ of spatial resolution and precision of $1 \mathrm{~mm}$ extracted with Global Navigation Satellite System (GNSS) - Real-time kinematic (RTK) System South Galaxy Model G1.

Each UAV survey site is located in a different coastal barrier geological setting according to the [61]'s classification that recognized progradational or transgressive barriers (the dune field migrates towards the mainland), agradational barriers (stationary tendency of dune field) and retrogradational or regressive barriers (the dune field migrates towards the ocean) (Table 3).

Table 3. Barrier types and urban areas class gathered on twelve cities group.

\begin{tabular}{|c|c|c|c|c|}
\hline ID & Barrier ID & Barrier Type & Counties & Locations \\
\hline 1 & B & $\begin{array}{l}\text { Progradational - Transgres- } \\
\text { sive dune fields }\end{array}$ & $\begin{array}{l}\text { Torres, Arroio do Sal, Terra de Areia, } \\
\text { Capão da Canoa, Xangri-lá }\end{array}$ & $\begin{array}{l}\text { Torres, Praia do } \\
\text { Arroio Seco, Praia da } \\
\text { Riveira, Praia Santa } \\
\text { Helena, Praia Estrela } \\
\text { do Mar, Rondinha, } \\
\text { Areias Brancas, } \\
\text { Arroio do Sal, } \\
\text { Curumim, Arroio } \\
\text { Teixeira, Capão } \\
\text { Novo, and Capão da } \\
\text { Canoa. }\end{array}$ \\
\hline 2 & $\mathrm{C}$ & $\begin{array}{l}\text { Aggradational - } \\
\text { Transgressive dune fields }\end{array}$ & Xangri-lá, Osório, Imbé & $\begin{array}{l}\text { Noiva do Mar, } \\
\text { Rainha do Mar, Santa } \\
\text { Terezinha, Albatroz, } \\
\text { Mariluz, and Imbé. }\end{array}$ \\
\hline 3 & $\mathrm{E}$ & $\begin{array}{l}\text { Retrogradational - Transgres- } \\
\text { sive dune fields }\end{array}$ & Tramandaí & Tramandaí \\
\hline 4 & $\mathrm{C}$ & $\begin{array}{l}\text { Aggradational - } \\
\text { Transgressive dune fields }\end{array}$ & \multicolumn{2}{|c|}{$\begin{array}{c}\text { Tramandaí, Cidreira, Balneário PinhalJardim do Éden, and } \\
\text { Cidreira }\end{array}$} \\
\hline 5 & $\mathrm{D}$ & $\begin{array}{l}\text { Retrogradational - Transgres- } \\
\text { sive dune fields }\end{array}$ & & $\begin{array}{l}\text { Balneário Pinhal, } \\
\text { Balneário Magistério, } \\
\text { Balneário Quintão } \\
\text { Novo, Praia do Farol } \\
\text { da Solidão, São } \\
\text { Simão, and Balneário } \\
\text { Mostardense }\end{array}$ \\
\hline 6 & $\mathrm{E}$ & $\begin{array}{l}\text { Retrogradational - Transgres- } \\
\text { sive dune fields }\end{array}$ & $\begin{array}{l}\text { Balneário Pinhal, Palmares do Sul, } \\
\text { Mostardas }\end{array}$ & Bojuru \\
\hline 7 & A & $\begin{array}{l}\text { Progradational - Relict Fore- } \\
\text { dunes and } \\
\text { Transgressive dunes }\end{array}$ & \multicolumn{2}{|c|}{$\begin{array}{c}\text { Mostardas, Tavares, São José do NortePraia do Mar Grosso } \\
\text { and Cassino }\end{array}$} \\
\hline 8 & $\mathrm{~B}$ & $\begin{array}{l}\text { Progradational - Transgres- } \\
\text { sive dune fields }\end{array}$ & Santa Vitória do Palmar & Saritas \\
\hline 9 & $\mathrm{C}$ & $\begin{array}{l}\text { Aggradational - Transgres- } \\
\text { sive dune fields }\end{array}$ & Santa Vitória do Palmar & Verga \\
\hline 10 & $\mathrm{D}$ & $\begin{array}{l}\text { Retrogradational - Transgres- } \\
\text { sive dune fields }\end{array}$ & Santa Vitória do Palmar & Hermenegildo \\
\hline 11 & $\mathrm{E}$ & $\begin{array}{l}\text { Retrogradational - Transgres- } \\
\text { sive dune fields }\end{array}$ & Santa Vitória do Palmar & Concheiros \\
\hline 12 & $\mathrm{~F}$ & $\begin{array}{l}\text { Retrogradational (Mainland } \\
\text { Beach) - Transgressive dune } \\
\text { fields }\end{array}$ & Santa Vitória do Palmar & Barra do Chuí \\
\hline
\end{tabular}


The Bruun Rule for Google Earth Engine Model (BRGM) allowed extracting the result of Bruun Rule Equation with a simple vector line and a raster with the topo-bathymetric information to obtain the berm height or the dune foot, and the depth of closure of active beach profile.

The berm height was determined manually on BRGM analyzing the slope variation of the DEM derived from UAV survey data (Figure 2). The depth of closure was based on [65]'s results, using the same technique of morphological indicators, recognizing the main changes in slope to delimit the lower shoreface for the Bruun Rule. The results of the Hallermeier DoC equation [22] to the region are between $26.8 \mathrm{~m}$ and $37.9 \mathrm{~m}$ [62]. The bathymetry raster for the region was obtained exporting the data of the Coastal Modeling System (SMC - Brazil [63]) and interpolated on QGIS with Inverse Distance Weight (IDW) method. The berm height and DoC were extracted on the twelve profiles under RCP scenarios: 4.5 and 8.5 for 2100 .
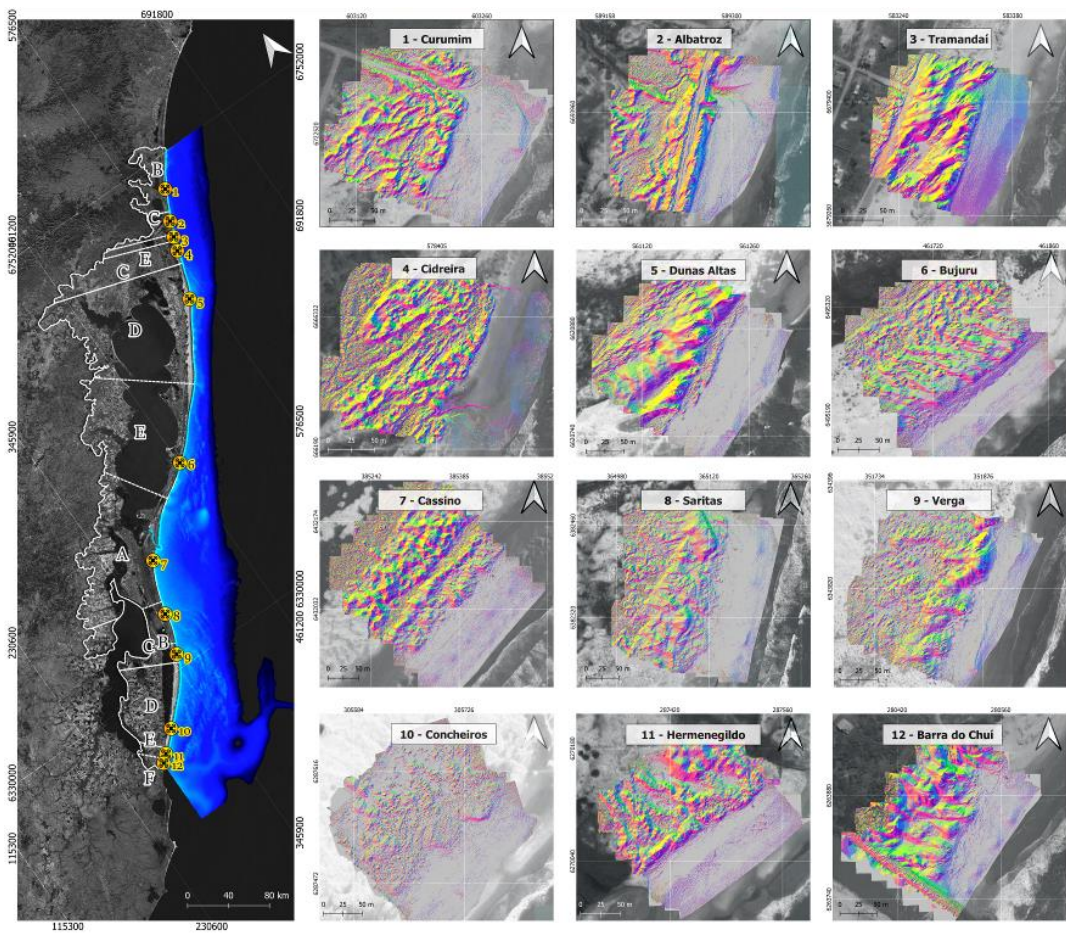

UAV Surveys and SMC Bathymetry
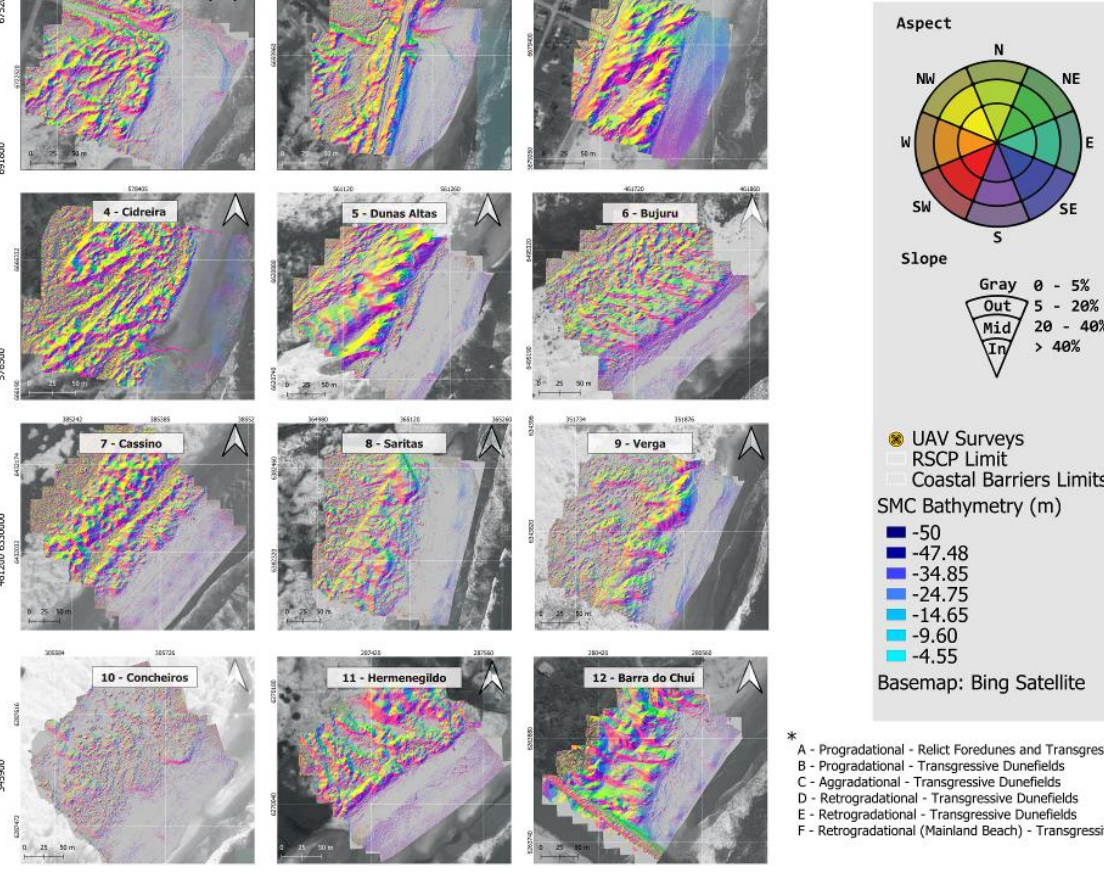

* UAV Surveys
RSCP Limit

Coastal Barriers Limits* SMC Bathymetry (m)

드 -50

-47.48
-34.85

-34.85
-24.75
-14.65

$-14.65$

$-9.60$

Basemap: Bing Satellite$$
\text { Basemap. Bing Satellite }
$$

* A - Progradational - Relict Foredunes and Transgressive Dunes B- Progradational - Transgressive Dunefields
C-Aggradational - Transgressive Dunefields D- Retrogradational - Transsressive Dunefields
E- Retrogradational - Transgressive Dunefields E Retrogradational - Transgressive Dunefields
F- Retrogradational (Mainland Beach) - Transgressive Dunefields

Figure 2. UAV surveys and SMC bathymetry. The DEM derived from data of UAV Survey is represented with slope-aspect showing the direction and the percentage of the slope. The gray represents $0-5 \%$ of slope, Out: $5-20 \%$, Mid: $20-40 \%$, In: $>40 \%$.

\section{Results}

\subsection{End Point Rate for QGIS (EPR4Q)}

The visual analysis of the classification of the shoreline trend based on changes in tidal flats demonstrates that the best years to perform the EPR are 1992 and 2016 (Figure 3). The shoreline displacement shows considerable variability during the next decades across the RS coast (Figure 4). 

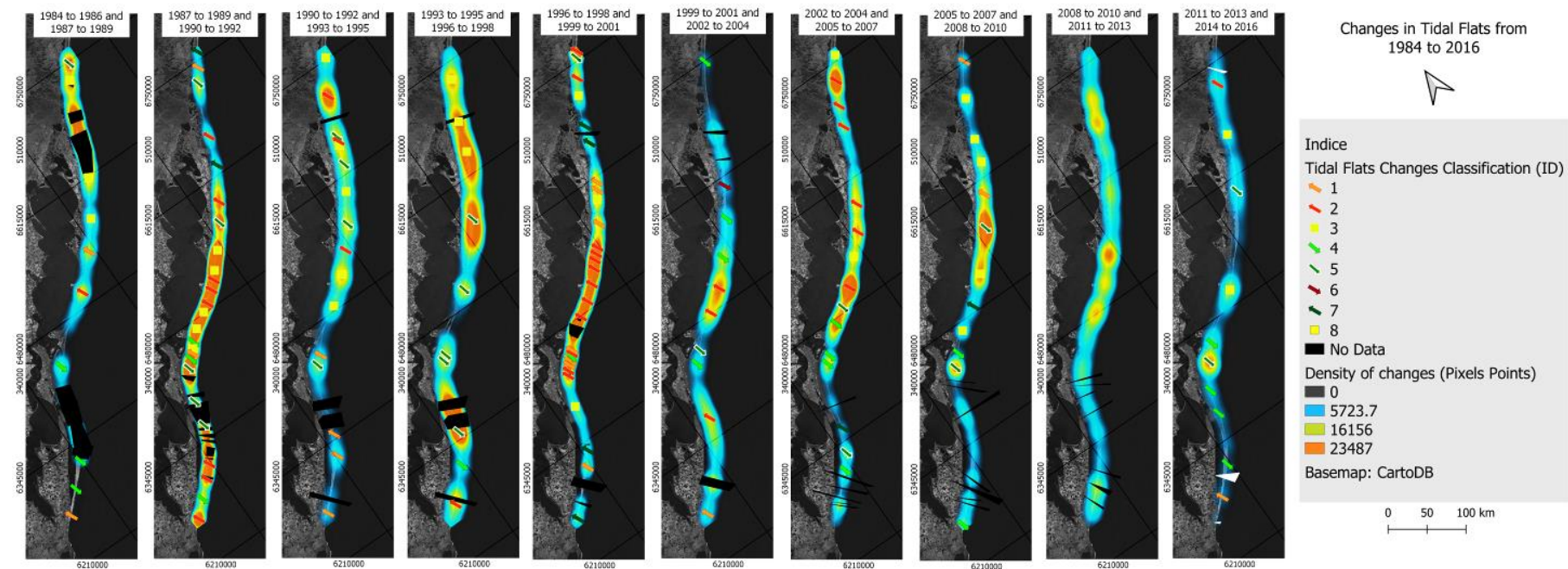

Figure 3. Heatmaps and classification according to Table 1 of changes in tidal flats from 1984 to 2016 on RSCP coast.

The values of the EPR ranges from $940 \mathrm{~m}$ to $-502 \mathrm{~m}$ for the period 2016 - 2100 that corresponds with a shoreline change rate of $8.7 \mathrm{~m} . \mathrm{yr}^{-1}$ and $-4.7 \mathrm{~m} . \mathrm{yr}^{-1}$, respectively (Figure 4). Negative values of EPR indicate an erosional trend, while the positive ones indicate an accretion trend. Regardless of the mouth of Patos Lagoon (Cassino and Praia do Mar Grosso, Figure 4) that revealed accretion, the results have shown a mean shoreline retreat rate with values of $-0.5 \mathrm{~m} \cdot \mathrm{yr}^{-1}$ in the south and middle of the RS coast, which seems to concentrate in the southern portion of the large-scale coastal projection. In the north, the shoreline is more stable with relative small retreat rates, and an accretion rate about 8.7 $\mathrm{m} . \mathrm{yr}^{-1}$ can be pointed at the mouth of Patos Lagoon. 


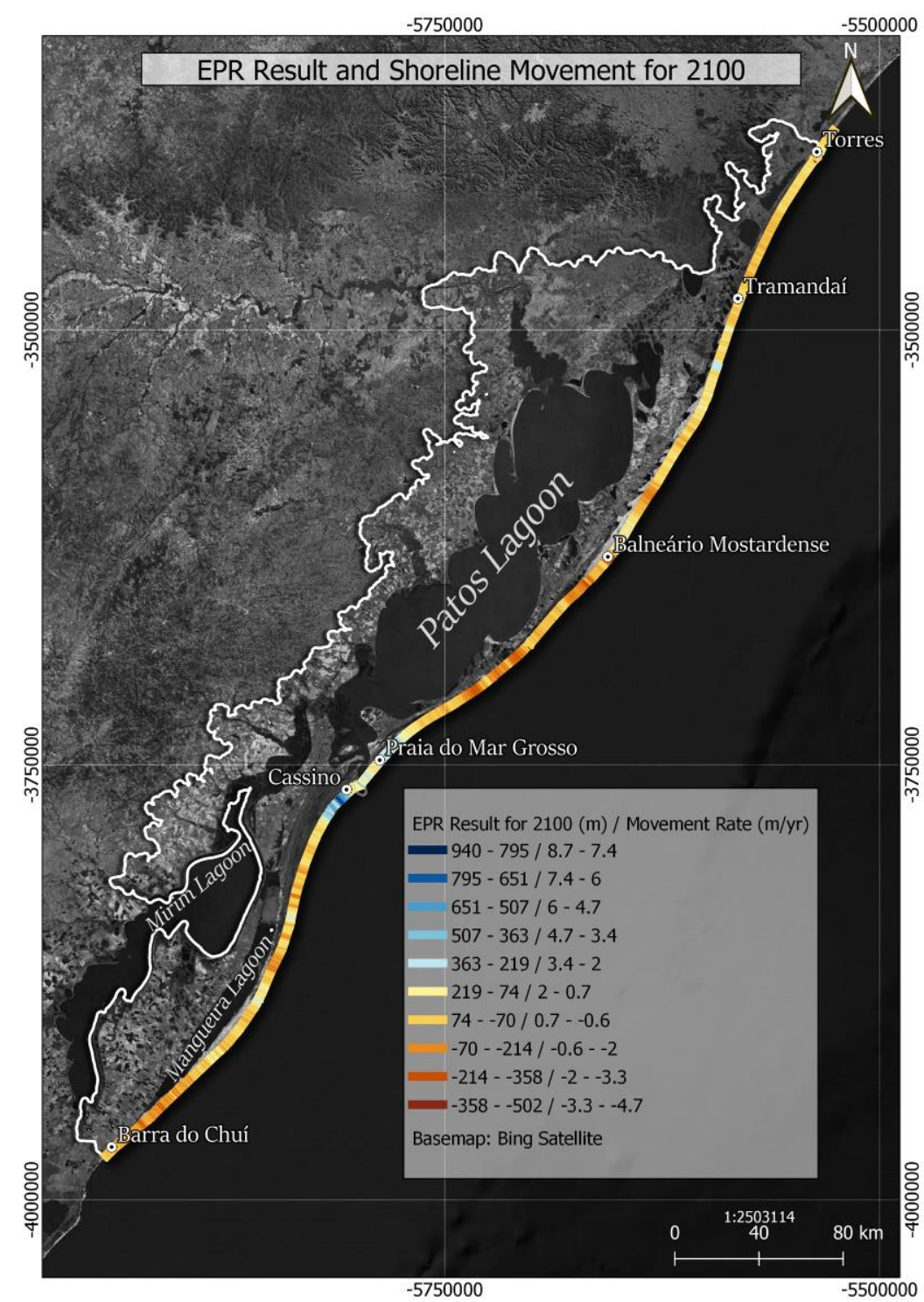

Figure 4. EPR4Q results: shoreline movement $(\mathrm{m})$ and change rate $\left(\mathrm{m} . \mathrm{yr}^{-1}\right)$ for 2100.

Figure 5 displays with more detail the shoreline movement on Patos Lagoon region according to EPR predictions. The maximum advance of the shoreline was reached in Cassino beach (Rio Grande) and Mar Grosso beach (São José do Norte) with a total value of $1268 \mathrm{~m}$ (Figure $5-9$ and 10). The maximum retreat of the shoreline was found in the extreme south (Hermenegildo beach) with values of $-345 \mathrm{~m}$ (Figure 5 -11).

On the north coast, Capão da Canoa and Xangri-lá beaches presented higher shoreline retreatment (-245 $\mathrm{m}$ in total) (Figure $5-3$ and 4). However, Torres, Arroio do Sal, Imbé, Tramandaí, Cidreira, and Balneário do Pinhal showed stable and positive values of the shoreline (maximum of $574 \mathrm{~m}$ ) (Figure 5). In the center of the map, the Balneário Mostardense (Figure 5 - 8) might be the most impacted place showing a shoreline with a maximum retreat of $-449 \mathrm{~m}$. This retreat can affect directly the city by the end of the century, due to the fact that nowadays, the distance from the coastline to the city is about $100 \mathrm{~m}$. 

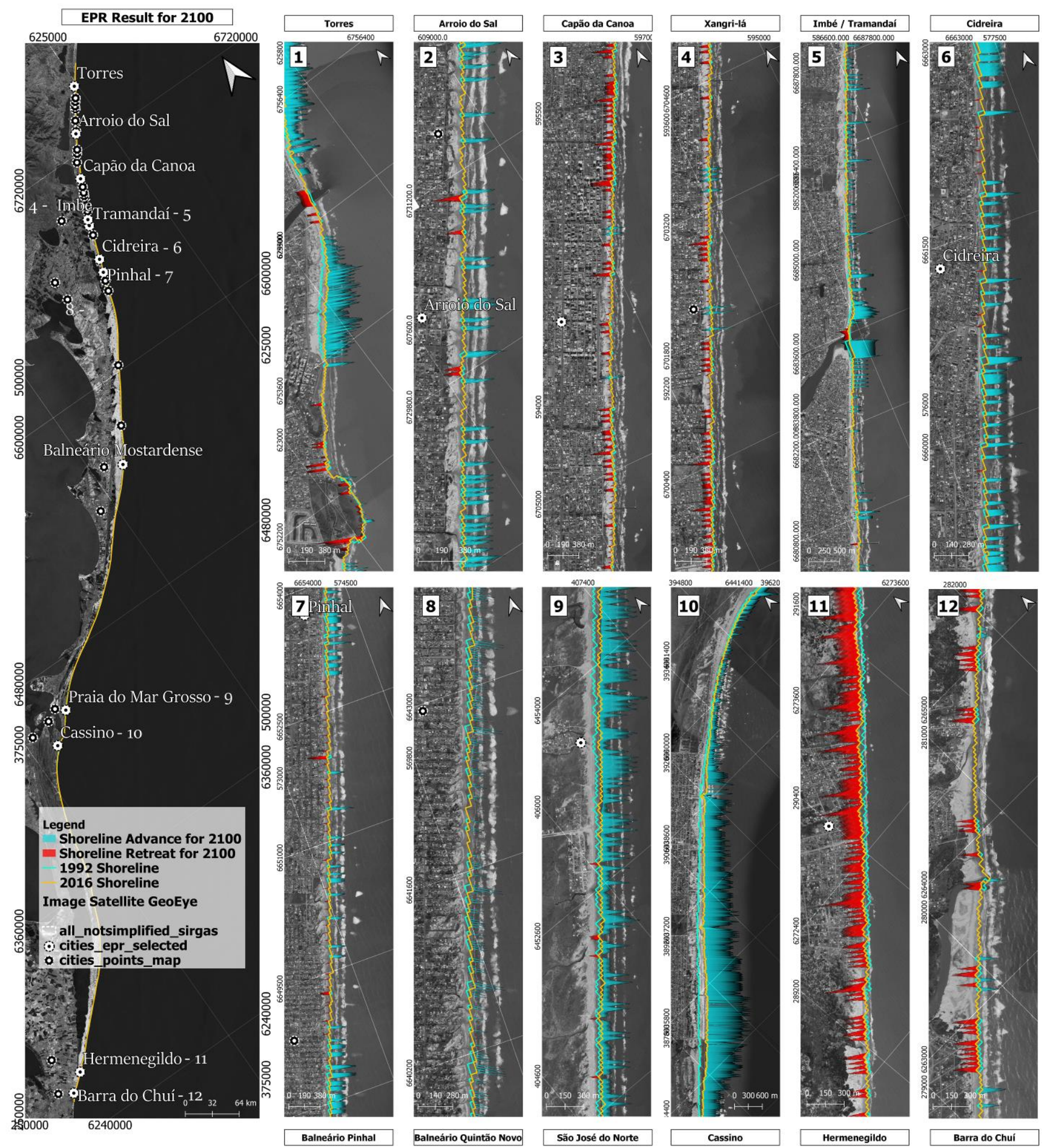

Figure 5. Graphical EPR in the main cities and beaches of the RS coast. The red color indicates the predicted shoreline retreat and the blue color the predicted advance of the shoreline for 2100 .

\subsection{Uncertainty Bathtub Model (uBTM)}

\subsection{1. uBTM with AW3D30 DTM - RCP 4.5}

The results of the Uncertainty Bathtub Model, using the AW3D30 under the RCP 4.5, scenario showed a total of 3811 hectares (ha) of urban area with $\geq 13 \%$ probability of all RSCP being affected by the sea-level rise flood in 2100 (Figure 6) (Table 4). 
The urban areas of Rio Grande group are the region with the highest potential to be exposed to sea-level rise impacts, showing 1095.11 ha with a probability $\geq 13 \%$. It is possible to identify zones of potential flooding around the city, on the Port of Rio Grande and Cassino beach (Figure 6 - 6).

The Littoral North Cities Group 2 (LNGC2) are the urban areas more impacted by sea-level flood with 8 ha showing $100 \%$ of probability and the second group in the list with a high total area of $\geq 13 \%$ of probability to be flooded, 969.14 ha. It is possible to observe a large urban area around the Tramandaí River that can be seriously affected (Figure $6-2)$.

The Littoral North Cities Group 1 (LNGC1) is also highly exposed to sea-level flood impact showing 290.93 ha with a probability $\geq 13 \%$ (Figure $6-1$ ).

Table 4. Results of uBTM under RCP 4.5 scenario - sea-level elevation of 0.46 m (0.31 - 0.63 )

Area (ha)

\begin{tabular}{|c|c|c|c|c|c|c|c|c|c|c|c|c|}
\hline $\begin{array}{c}\text { Probabil- } \\
\text { ity }(\%)\end{array}$ & $\begin{array}{c}\text { LNGC } \\
1\end{array}$ & $\begin{array}{c}\text { LNGC } \\
2\end{array}$ & $\begin{array}{c}\text { LNGC } \\
3\end{array}$ & $\begin{array}{c}\text { Mo- } \\
\text { stardas }\end{array}$ & SJN & $\begin{array}{c}\text { Rio } \\
\text { Grand } \\
\text { e } \\
\end{array}$ & $\begin{array}{l}\text { Chuí and } \\
\text { Herme- } \\
\text { negildo }\end{array}$ & $\begin{array}{c}\text { MAPO } \\
\text { A }\end{array}$ & $\begin{array}{c}\text { BR } \\
\text { and } \\
\text { Tapes }\end{array}$ & $\begin{array}{c}\text { Aramba- } \\
\text { ré and } \\
\text { SRS }\end{array}$ & SLS & $\begin{array}{c}\text { Pelo- } \\
\text { tas }\end{array}$ \\
\hline 0 & $\begin{array}{c}3688.0 \\
5\end{array}$ & $\begin{array}{c}9948.9 \\
9\end{array}$ & $\begin{array}{c}2491.3 \\
5\end{array}$ & 461.952 & $\begin{array}{c}325.4 \\
7\end{array}$ & 3832.2 & 1019.29 & 49077.00 & $\begin{array}{c}775.8 \\
6\end{array}$ & 206.41 & $\begin{array}{c}634.6 \\
7\end{array}$ & 6362.73 \\
\hline 13 & 118.37 & 382.84 & 28.54 & 4.101 & 44.67 & 371.94 & 3.35 & 288.34 & 10.06 & 18.44 & 11.86 & 117.53 \\
\hline 25 & 88.087 & 284.91 & 13.76 & 1.626 & 40.97 & 313.80 & 2.28 & 203.46 & 10.46 & 16.61 & 7.89 & 76.14 \\
\hline 38 & 47.76 & 167.87 & 6.95 & 0.434 & 19.86 & 234.11 & 0.76 & 171.82 & 7.21 & 10.78 & 6.22 & 59.22 \\
\hline 50 & 25.07 & 70.80 & 2.13 & 0.041 & 12.30 & 119.60 & 0.06 & 105.87 & 5.36 & 9.20 & 5.57 & 33.66 \\
\hline 63 & 6.40 & 29.24 & 0.12 & & 2.84 & 37.94 & & 28.48 & 2.02 & 8.30 & 2.10 & 32.84 \\
\hline 75 & 2.55 & 15.10 & 0.15 & & & 14.94 & & 7.96 & & 0.88 & & 4.21 \\
\hline 88 & 1.17 & 10.25 & 0.05 & & & 1.95 & & 4.97 & & 0.69 & & 0.05 \\
\hline 100 & 1.52 & 8.12 & & & & 0.84 & & 2.74 & & 0.29 & & 0.03 \\
\hline $\begin{array}{l}\text { Total Im- } \\
\text { pacted }\end{array}$ & 290.93 & 969.14 & 51.70 & 6.20 & $\begin{array}{c}120.6 \\
5\end{array}$ & 1095.11 & 6.45 & 813.63 & 35.11 & 65.19 & 33.63 & 323.68 \\
\hline
\end{tabular}

In Pelotas area is possible to distinguish three important spots of future sea-level flood impact: the center of the city, Laranjal beach and Colônia-Z3, a traditional fisher's community (Figure $6-12$ ). The total area with a probably $\geq 13 \%$ to be affected with sea-level rise is 323.68 ha.

In the Metropolitan Area of Porto Alegre (MAPOA), all the critical locations are situated on the margin of Guaíba River, from Ipanema beach, in the south, to Guaíba city in the north region (Figure $6-8$ ). The total area with probability $\geq 13 \%$ of being impacted reaches $813.63 \mathrm{ha}$, and the urban zone is the third-largest potential stricken area.

The groups of urban areas of SJN (120.65 ha), Arambaré and SRS (65.19 ha), LNGC 3 (51.70 ha), BR and Tapes ( $35.11 \mathrm{ha})$, and SLS (33.63 ha) are also most likely urban area impacted in 2100, in contrast with Chuí and Hermenegildo (6.45 ha), and Mostardas (6.20 ha) that are the group with less than 10 ha of total area effect (Figure 6). 


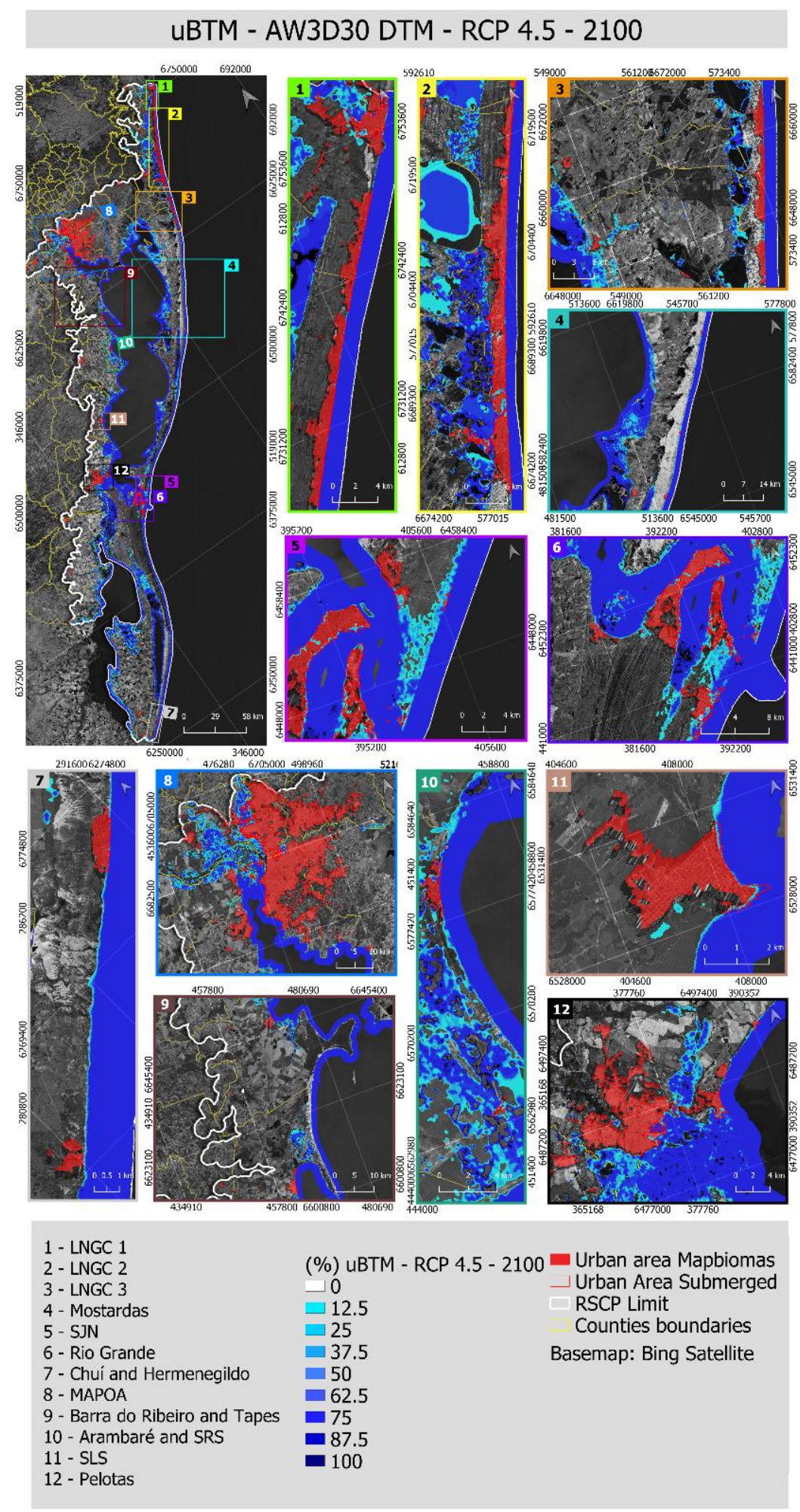

Figure 6. Map of sea-level flood probability using uBTM on AW3D30 DTM: RCP 4.5 scenario sea-level elevation of $0.46 \mathrm{~m}(0.31-0.63)$.

\subsection{2. uBTM with AW3D30 DTM - RCP 8.5}

Considering the RCP 8.5 scenario, there is an increase of 64627 ha of zones with a probability $\geq 13 \%$ to be affected by the sea-level rise in 2100 (Figure 7).

The critical urban area of the Rio Grande group shows an increase of 153.96 ha flooded when compared with the previous scenario (Table 5). The Metropolitan Area of Porto Alegre (MAPOA) is the one that presents the highest probability to be flooding by 
the sea-level rise, showing 4.41 ha with $100 \%$ of probability. The groups of cities SJN (137.16 ha), Arambaré and SRS (74.33 ha), LNGC 3 (67.51 ha), SLS (41.32 ha), and BR and Tapes (40.40 ha) (Figure 7 - 5, 10, 3, 11 and 9, respectively) are also considered at risk, in contrast with Mostardas (9.07 ha) (Figure 7 - 4) and Chuí and Hermenegildo (7.65 ha) (Figure 7 - 7) where less than 10 ha are affected (Table 5).

Table 5. Results of uBTM with RCP 8.5 scenario - sea-level elevation of 0.68 m (0.50 - 0.90).

\begin{tabular}{|c|c|c|c|c|c|c|c|c|c|c|c|c|}
\hline \multirow[b]{2}{*}{$\begin{array}{c}\text { Probabil- } \\
\text { ity (\%) }\end{array}$} & \multicolumn{12}{|c|}{ Area (ha) } \\
\hline & $\begin{array}{c}\text { LNGC } \\
1\end{array}$ & $\begin{array}{c}\text { LNGC } \\
2\end{array}$ & $\begin{array}{c}\text { LNGC } \\
3\end{array}$ & $\begin{array}{c}\text { Mo- } \\
\text { stardas }\end{array}$ & SJN & $\begin{array}{l}\text { Rio } \\
\text { Grand } \\
\text { e }\end{array}$ & $\begin{array}{l}\text { Chuí and } \\
\text { Herme- } \\
\text { negildo }\end{array}$ & $\begin{array}{c}\text { MAPO } \\
\text { A }\end{array}$ & $\begin{array}{c}\text { BR } \\
\text { and } \\
\text { Tape } \\
\text { s }\end{array}$ & $\begin{array}{l}\text { Aramba- } \\
\text { ré and } \\
\text { SRS }\end{array}$ & SLS & Pelotas \\
\hline 0 & $\begin{array}{c}3634.7 \\
8\end{array}$ & $\begin{array}{c}9798.0 \\
1\end{array}$ & $\begin{array}{c}2475.5 \\
3\end{array}$ & 419.08 & $\begin{array}{c}308.9 \\
5\end{array}$ & 3678.24 & 1018.09 & 48912.57 & $\begin{array}{c}770.5 \\
6\end{array}$ & 197.27 & $\begin{array}{c}626.9 \\
7\end{array}$ & 6297.65 \\
\hline 13 & 121.15 & 382.44 & 32.29 & 5.52 & 51.99 & 378.52 & 3.18 & 358.95 & 10.43 & 21.78 & 14.95 & 143.27 \\
\hline 25 & 102.15 & 335.73 & 20.20 & 2.59 & 38.85 & 334.97 & 2.61 & 216.50 & 9.42 & 16.67 & 10.07 & 86.58 \\
\hline 38 & 64.49 & 212.01 & 9.70 & 0.74 & 22.34 & 269.58 & 1.57 & 192.11 & 9.16 & 12.66 & 5.82 & 64.60 \\
\hline 50 & 36.30 & 105.51 & 4.46 & 0.23 & 15.40 & 167.44 & 0.29 & 129.53 & 6.98 & 9.33 & 5.24 & 42.76 \\
\hline 63 & 13.80 & 43.95 & 0.66 & & 8.32 & 64.30 & & 57.56 & 3.89 & 9.16 & 4.63 & 30.56 \\
\hline 75 & 3.05 & 19.37 & 0.15 & & 0.26 & 29.26 & & 14.30 & 0.52 & 3.56 & 0.61 & 20.70 \\
\hline 88 & 1.75 & 11.08 & 0.05 & & & 3.73 & & 4.70 & & 0.69 & & 0.24 \\
\hline 100 & 1.51 & 10.02 & & & & 1.20 & & 4.41 & & 0.49 & & 0.05 \\
\hline $\begin{array}{l}\text { Total Im- } \\
\text { pacted }\end{array}$ & 344.21 & $\begin{array}{c}1120.1 \\
2\end{array}$ & 67.51 & 9.07 & $\begin{array}{c}137.1 \\
6\end{array}$ & 1249.08 & 7.65 & 978.07 & 40.40 & 74.33 & 41.32 & 388.76 \\
\hline
\end{tabular}

The Littoral North Cities Group 2 (LNCG 2) has a probability of $\geq 13 \%$ to be flooded that correspond to an area of 150.98 ha (Figure 7 -2). The LNCG 1 shows a growth of 53.27 ha (Figure $7-1$ ), and Pelotas of 65.07 ha (Figure 7 - 12). 


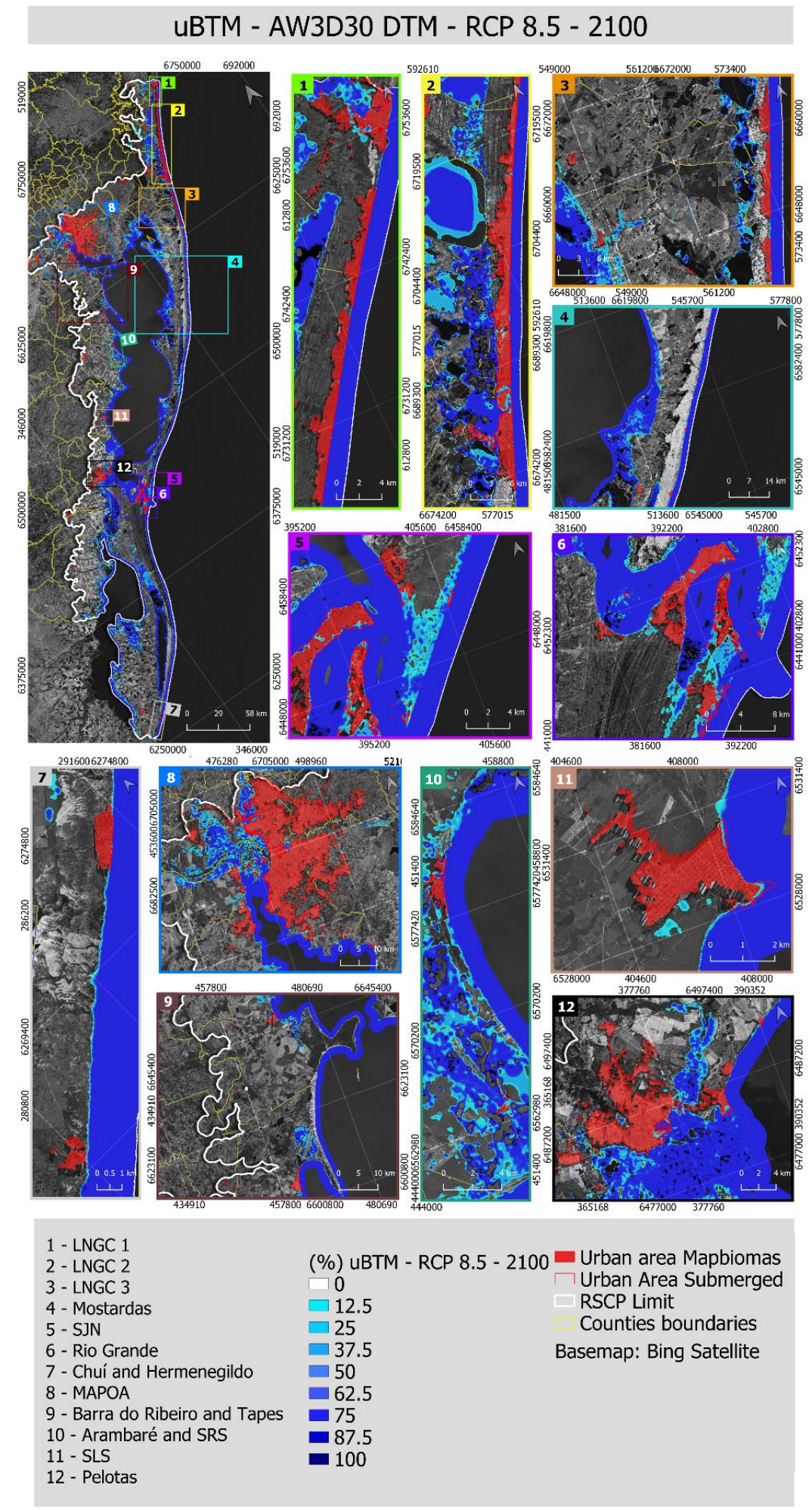

Figure 7. Map of sea-level flood probability using uBTM on AW3D30 DTM: RCP 8.5 scenario, sea level rise of $0.68 \mathrm{~m}(0.50-0.90)$.

\subsection{Bruun Rule for GEE model (BRGM)}

The total median retreat obtained by the BRGM for the RSCP coast it's about -593.29 $\mathrm{m}$ (RCP 4.5 scenario) and $-860.07 \mathrm{~m}$ (RCP 8.5 scenario). The results allow distinguishing two distinctive sectors (Table 6). The first one (Profiles 1 to 6, Figure 8), in the northern of the RSCP, shows a retreat that varies between $-298.46 \mathrm{~m}$ and $-453 \mathrm{~m}$ (in RCP 4.5 scenario), and between $-430.3 \mathrm{~m}$ and $-661.67 \mathrm{~m}$ (in RCP 8.5 scenario). 
Table 6. Results of BRGM for 2100 using RCP 4.5 and 8.5 scenarios.

\begin{tabular}{cccccc}
\hline ID & $\begin{array}{c}\text { Berm } \\
\text { Height (m) }\end{array}$ & Depth of Closure (m) & Profile Length (m) & $\begin{array}{c}\text { BRGM } \\
\text { RCP 4.5 (m) }\end{array}$ & $\begin{array}{c}\text { BRGM } \\
\text { RCP 8.5 (m) }\end{array}$ \\
\hline 1 & 1.93 & -19.13 & 1286.28 & -365.9 & -526.84 \\
2 & 2.20 & -20.58 & 3340.12 & -405.87 & -582.51 \\
3 & 2.28 & -21.07 & 4504.62 & -396.58 & -566.32 \\
4 & 2.46 & -20.42 & 3488.99 & -385.06 & -559.23 \\
5 & 2.78 & -16.00 & 5649.48 & -298.46 & -430.3 \\
6 & 3.03 & -13.90 & 3438.02 & -453.29 & -661.67 \\
7 & 2.68 & -9.33 & 2294.33 & -1030.67 & -1429.38 \\
8 & -0.42 & -10.33 & 5123.04 & -767 & -1134.12 \\
9 & 1.67 & -10.73 & 1570.93 & -733.3 & -1058.48 \\
10 & 0.20 & -13.64 & 2884.53 & -779.12 & -1136.57 \\
11 & 5.76 & -12.51 & 2488.42 & -1184.04 & -1726.89 \\
12 & 2.39 & -14.05 & 1910.39 & -951.73 & -1390.06 \\
\hline
\end{tabular}

The southern region of the RSCP is the most hazardous area (Profiles 7 to 12, Figure 8) because includes the cities of Cassino, Hermenegildo and Barra do Chuí and displays very high retreat values from $-733.3 \mathrm{~m}$ to $-1184.04 \mathrm{~m}$ (RCP 4.5 scenario), and from $-1134.12 \mathrm{~m}$ to $-1726.89 \mathrm{~m}$ (RCP 8.5 scenario).
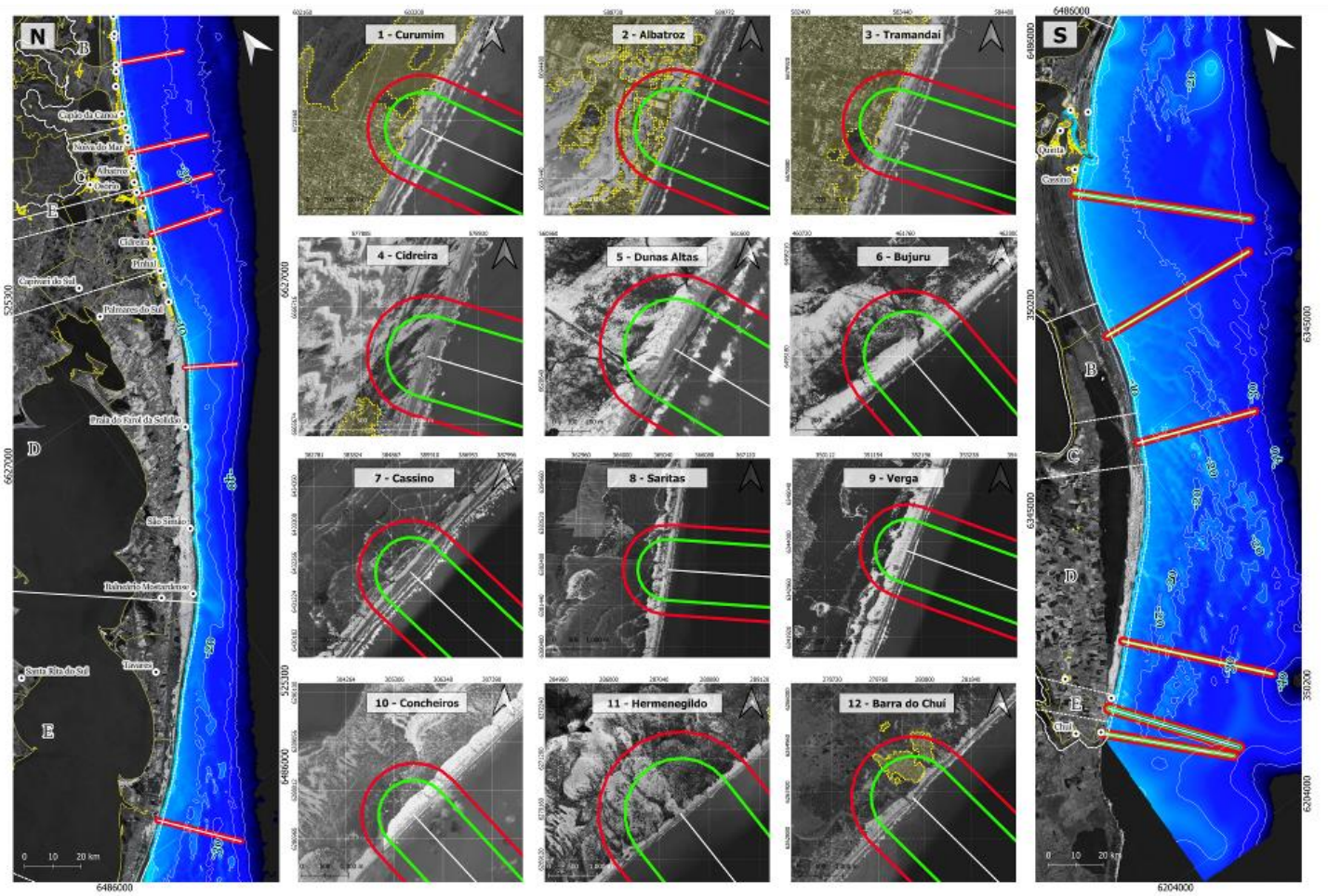
BRGM Results - RCP 4.5 and RCP 8.5
sea-level rise scenarios for 2100
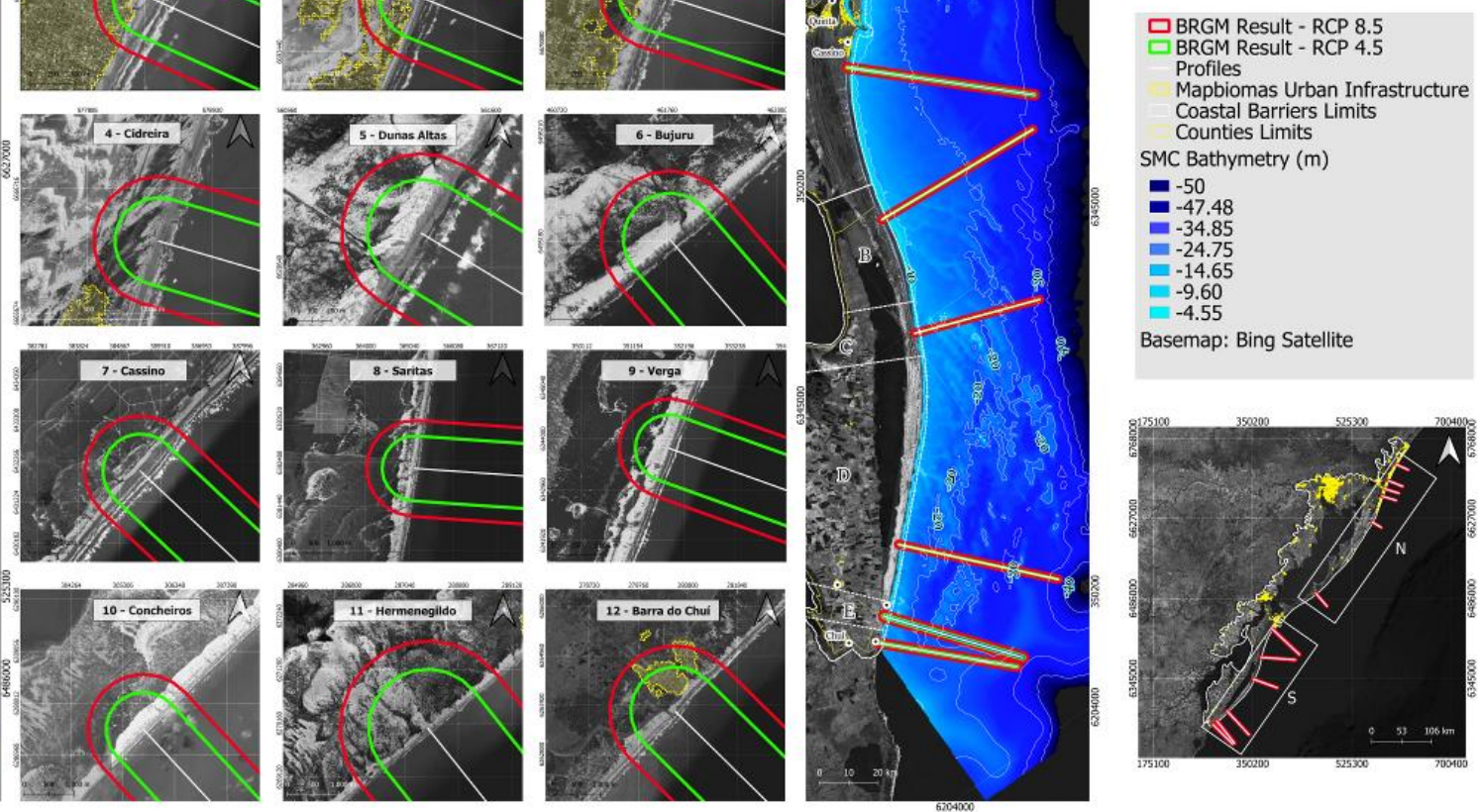

Figure 8. BRGM results for the 12 profiles along the sandy barrier of RSCP. The result is graphically represented by a buffer vector, where the extreme edge located in front of the line is the final expected in 2100 under RCP4.5 (green) and RCP 8.5 (red) scenarios.

\section{Discussion}

The application of the models gives three different perspectives of sea-level impact analysis for supporting decision-makers of Rio Grande do Sul coastal plain. EPR4Q results reveal that approximately $28.60 \%$ of the RSCP shoreline might show coastal erosion 
and $1.11 \%$ severe erosion (i.e. shoreline retreat $>-0.5 \mathrm{~m} . \mathrm{yr}^{-1}$ and $>-3 \mathrm{~m} . \mathrm{yr}^{-1}$, respectively as stated in [12] 's classification). According to [61], from 2002 to 2016, about $4 \%$ of the RSCP shorelines showed values $\left(>-2.73 \mathrm{~m} \cdot \mathrm{yr}^{-1}\right)$ that is considered as severe coastal erosion. Therefore, the present data shows that results are lower in EPR4Q (1.11\%). The difference can be explained by the fact that the value proposed by [61] is estimated by extrapolation of punctual measures of shoreline across RS coast, and the value in this study was obtained from a unique and integrated dataset, that analyzed 123532 transects of the entire RS coast, suggesting that the value $1.11 \%$ for severe coastal erosion is more precise.

The results of shoreline trends using EPR4Q show that the most affected cities are Balneário Mostardense, Hermenegildo, Barra do Chuí, Capão da Canoa, and Xangri-lá.

Balneário Mostardense displays a seasonal variance on shoreline movement related with the geomorphological characteristics that induce a slightly coastal inflection, and a greater exposition to the waves in storm regime [62] (Figure 5). [62]'s study indicated a shoreline retreat of $-13.8 \mathrm{~m}$ due to those extreme high-energy events in the period 09-05-2005 to 09-09-2005. Furthermore, [63] observed a total retreat of $-19 \mathrm{~m}$ (i.e. shoreline

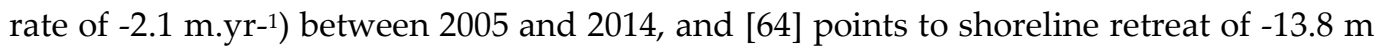
from 2016 to 2017 . The mean shoreline rate value calculated by EPR4Q is $-1.88 \mathrm{~m}$.yr-1 for the period 1992 - 2016, and the expected mean shoreline retreat is of $-202.67 \mathrm{~m}$ in 2100 . The mean value does not differ much from [63], otherwise is more moderate, but is quite distinct from the $-13.8 \mathrm{~m}$ found by [62] in the short-term analysis. The reason is due to the variability in shoreline displacement that occurs on temporal scales which range from months to years [65]. The method to analyze spatial variability through density maps avoids this problem because it visually identifies the variation of accretion and erosion between the years, which allows to select those with less variation caused by seasonal variability and extreme events. Moreover, the extracted shorelines between 1996 and 2001 shows similar distribution values as the ones found by [66] in the period 1997-1999, increasing the consistency of the method used.

A shoreline accretion trend was previously found in Torres $(>3$ m.yr-1), Tramandaí and Imbé $\left(<1.0 \mathrm{~m} \cdot \mathrm{yr}^{-1}\right)$, and Cassino $\left(>\sim 3 \mathrm{~m} \cdot \mathrm{yr}^{-1}\right)$ using end point rate method [67]. The study performed by [68] in Hermenegildo, using the least square method, revealed a shoreline total retreat of $-151.57 \mathrm{~m}$ in 2100 which is a value comparable with the mean -136.22 and median retreat $-164.68 \mathrm{~m}$, calculated for the Hermenegildo in this work with EPR.

The uBTM analysis makes it clear that Rio Grande, MAPOA, LNCG 2, and Pelotas are the groups of cities with more probability (between 13\% and 50\%) to be impacted with sea-level flood under RCP 4.5, and RCP 8.5 scenarios by the end of the century. Additionally, LNCG 2, MAPOA, LNCG 1, and Rio Grande are the group of cities with the greater area ( $100 \%$ of probability) to be impacted by the sea-level rise flood under both scenarios due to geomorphological aspects, low altitude coast and great topographic uniformity. Nowadays, Tramandaí (LNCG 2) and Cassino (LNCG 1) are affected by washover episodes, storms surge induced by cyclones, and even meteorological giant waves as on 9 February 2014 at Cassino Beach, near the Rio Grande city [69-71]. The [72]'s study using a bathtub to evaluate the sea-level flood with high precision digital elevation model revealed the sea rise can impact the urban infrastructures by the end of the century as uBTM results pointed in both RCP 4.5 and RCP 8.5 scenarios.

The results given by the BRGM exceeded the retreat predicted in Hermenegildo in comparison to those obtained with the Random Shoreface Translation Model (RanSTM) [73-76]. [73] obtained a mean retreat distance of $-521 \mathrm{~m}$ for 2100 using sea-level projections provided by the IPCC 2007-AR4. [77] found a mean retreat of $-567 \mathrm{~m}$ using the projections of IPCC 2014-AR5 while [75] with the same sea-level projections released a mean retreat distance of $-716 \mathrm{~m}$ due to take into account the effect of coastal hard protection structures. BRGM using regional projection of IPCC SROCC points to the 2100 horizon values of $-1.18 \mathrm{Km}$ (RCP 4.5) and $-1.73 \mathrm{Km}$ (RCP 8.5). The differences can be explained by the fact that sea-level trend values are not the same, and the RanSTM model is a stochastic model that can deal with uncertainties in the input data, being more precise 
than deterministic models, such as the Bruun model that ignored this aspect. The model also considers that the volume of water that drains the lagoon does not change as well as the tidal channel remains active, and assumes that the sea-level affects in Patos Lagoon are similar to those observed along the coast. In all models (EPR4Q, uBTM, and BRGM) it is also assumed that the existing coastal defenses (i.e. jetties) and other anthropogenic interventions in southern region (i.e. dredging and nourishments operations) are kept by 2100. Locations as Cassino beach, Imbé and Tramandaí are particularly vulnerable to changes in sediment input, interventions in the jetties (extension or reconfiguration) and dredging operations because they can change the sediment supply to the beach system. The impact of other extreme events can be more aggressive in the cities when analyzed the UBTM results. It is essential to prevent the urban expansion in the following years in areas near the sea and margins of Patos Lagoon, in order to avoid an increase in exposure to the hazard processes and the risk level.

There are other important issues that were not purposes of this preliminary study. These aspects are related to possible changes in climate and oceanographic settings, such as the mean direction of the wind, the angle of incidence of the waves, longshore currents direction or storm regime, which must also be considered in future coastal planning.

\section{Conclusions}

The use of Free and Open-Source Software for GIS (FOSS4GIS), considering the new IPCC information about the SLR for the RS coast, allowed to perform a complete and unprecedented analysis in all coastal plain extension. The use of one elevation model, two shoreline changes analysis, and three different sea-level models brought robustness to the results.

It can be stated that using the EPR4Q model is predicted a maximum shoreline advance of $795 \mathrm{~m}$ in some areas and a maximum shoreline retreat of $-502 \mathrm{~m}$ by the end of the century. The shoreline retreat can majority threatening the cities of Balneário Mostardense, Hermenegildo, Barra do Chuí, Capão da Canoa, and Xangri-lá.

The sea-level flood analysis using the UBTM estimates that the urban areas can lose $38.11 \mathrm{Km}^{2}$ and $44.57 \mathrm{Km}^{2}$ in 2100 under the RCP 4.5 and RCP 8.5 scenarios, respectively. Examples of cities with high potential to be impacted by the sea-level flood are Tramandaí, Imbé, Porto Alegre, Pelotas, and Rio Grande.

The BRGM shows that the southern part of RSCP, where the cities of Cassino, Barra do Chuí, and Hermenegildo are situated, can be more affected by sea-level rise. The minimum retreat found was $-298.46 \mathrm{~m}$ (RCP 4.5), and the maximum retreat noticed was $-1.7 \mathrm{~km}(\mathrm{RCP} 8.5)$ for the end of 2100.

Other studies have already identified coastal hazards as coastal erosion and flooding in the same cities found in this work, proving that is possible to create a completed sea-level analysis using only free and open-source software. In addition, it is prudent for local coastal managers of other cities in RSCP that exhibit some value of impact to pay attention to the increase of coastal exposure.

Funding: L.T. L. is grateful to the Brazilian National Council for Scientific and Technological Development (CNPq) for the CSF's (Ciência sem Fronteiras) program doctoral fellowship granted (249636/2013-1). Thanks are due to FCT/MCTES for the financial support to CESAM (UIDP/50017/2020+UIDB/50017/2020), through national funds.

\section{References}

1. Hamlington, B.D.; Gardner, A.S.; Ivins, E.; Lenaerts, J.T.M.; Reager, J.T.; Trossman, D.S.; Zaron, E.D.; Adhikari, S.; Arendt, A.; Aschwanden, A.; et al. Understanding of Contemporary Regional Sea-Level Change and the Implications for the Future. Rev. Geophys. 2020, 58, e2019RG000672. 10.1029/2019RG000672.

2. Frederikse, T.; Landerer, F.; Caron, L.; Adhikari, S.; Parkes, D.; Humphrey, V.W.; Dangendorf, S.; Hogarth, P.; Zanna, L.; 
Cheng, L.; et al. The causes of sea-level rise since 1900. Nature 2020, 584, 393-397. 10.1038/s41586-020-2591-3.

3. Church, J.A.; White, N.J. Sea-Level Rise from the Late 19th to the Early 21st Century. Surv. Geophys. 2011, 32, 585-602. 10.1007/s10712-011-9119-1.

4. S, N.R.; for Atmospheric Research Staff (Eds), N.C. The Climate Data Guide: Global Mean Sea Level from TOPEX \& Jason Altimetry Available online: https://climatedataguide.ucar.edu/climate-data/global-mean-sea-level-topex-jason-altimetry (accessed on Dec 21, 2021).

5. Neumann, B.; Vafeidis, A.T.; Zimmermann, J.; Nicholls, R.J. Future Coastal Population Growth and Exposure to Sea-Level Rise and Coastal Flooding - A Global Assessment. PLoS One 2015, 10. 10.1371/journal.pone.0118571.

6. Mengel, M.; Nauels, A.; Rogelj, J.; Schleussner, C.-F. Committed sea-level rise under the $\{$ Paris\} \{Agreement $\}$ and the legacy of delayed mitigation action. Nat. Commun. 2018, 9, 601. 10.1038/s41467-018-02985-8.

7. Bird, E.C.F. Coastline changes: a global review. Coastline Chang. a Glob. Rev. 1985. 10.2307/632970.

8. Leatherman, S.P.; Zhang, K.; Douglas, B.C. Sea level rise shown to drive coastal erosion. Eos, Trans. Am. Geophys. Union 2000, 81, 55. 10.1029/00EO00034.

9. Stive, M.J.F. How important is global warming for coastal erosion? Clim. Change 2004.

10. Isla, F.I. Coastal Zones and Estuaries. In Coastal Zones and Estuaries; 2009 ISBN 978-1-84826-016-0.

11. Van Rijn, L.C. Coastal erosion and control. Ocean Coast. Manag. 2011. 10.1016/j.ocecoaman.2011.05.004.

12. Luijendijk, A.; Hagenaars, G.; Ranasinghe, R.; Baart, F.; Donchyts, G.; Aarninkhof, S. The State of the World's Beaches. Sci. Rep. 2018. 10.1038/s41598-018-24630-6.

13. Vousdoukas, M.I.; Ranasinghe, R.; Mentaschi, L.; Plomaritis, T.A.; Athanasiou, P.; Luijendijk, A.; Feyen, L. Sandy coastlines under threat of erosion. Nat. Clim. Chang. 2020. 10.1038/s41558-020-0697-0.

14. Passeri, D.L.; Hagen, S.C.; Medeiros, S.C.; Bilskie, M. V; Alizad, K.; Wang, D. The dynamic effects of sea level rise on low-gradient coastal landscapes: A review: The Dynamic Effects of Sea Level Rise on low-gradient coastal landscapes. Earth's Futur. 2015, 3, 159-181. 10.1002/2015EF000298.

15. Oppenheimer, M.; Glavovic, B.; Hinkel, J.; van de Wal, R.; Magnan, A.K.; Abd-Elgawad, A.; Cai, R.; Cifuentes-Jara, M.; DeConto, R.M.; Ghosh, T.; et al. Sea Level Rise and Implications for Low Lying Islands, Coasts and Communities. IPCC Spec. Rep. Ocean Cryosph. a Chang. Clim. 2019.

16. de Lima, L.T.; Fernández-Fernández, S.; Espinoza, J.M.A.; Albuquerque, M.G.; Bernardes, C. End Point Rate Tool for QGIS (EPR4Q): Validation using DSAS and AMBUR. 2021. 10.20944/preprints202101.0082.v1.

17. Himmelstoss, E.A.; Henderson, R.E.; Kratzmann, M.G.; Farris, A.S. Digital Shoreline Analysis System ( DSAS ) Version 5.0 User Guide. Open-File Rep. 2018-1179 2018.

18. Williams, L.L.; Lück-Vogel, M. Comparative assessment of the GIS based bathtub model and an enhanced bathtub model for coastal inundation. J. Coast. Conserv. 2020. 10.1007/s11852-020-00735-x.

19. de Lima, L.T.; Fernández-Fernández, S.; Gonçalves, J..; Filho, M.L.; Cristina, B. Development of tools for coastal management in Google Earth Engine: Uncertainty Bathtub Model and Bruun Rule - Manuscript submitted for publication. Remote Sens. 2021, 22. (ISSN 2072-4292).

20. Li, X.; Grady, C.J.; Peterson, A.T. Delineating Sea Level Rise Inundation Using a Graph Traversal Algorithm. Mar. Geod. 2014. 10.1080/01490419.2014.902884.

21. Perini, L.; Calabrese, L.; Salerno, G.; Ciavola, P.; Armaroli, C. Evaluation of coastal vulnerability to flooding: comparison of two different methodologies adopted by the Emilia-Romagna region (Italy). Nat. Hazards Earth Syst. Sci. 2016, 16, 181-194. 10.5194/nhess-16-181-2016.

22. Bruun, P. Sea-Level Rise as a Cause of Shore Erosion. In Proceedings of the Proceedings of the American Society of Civil Engineers; 1962.

23. CIRIA Beach Management Manual 2010, 860 .

24. Hallermeier, R.J. A profile zonation for seasonal sand beaches from wave climate. Coast. Eng. 1980, 4, $253-277$. 
10.1016/0378-3839(80)90022-8.

25. Cooper, A.; Gerd, J.; Derek, P.; Giovanni, M.; Andy, C.; Bruno, S.; Kerrylee, C.; Edward, R.; Orrin, K.; Andrew, A.; et al. Sandy beaches can survive sea-level rise. EarthArXiv 2020.

26. Calliari, L.J.; Pereira, P.D.S.; Short, A.D.; Sobral, F.C.; Machado, A.A.; Pinheiro, Y.G.; Fitzpatrick, C. Brazilian Beach Systems cap. 19. Coast. Res. Libr. 2016.

27. Atkinson, A.L.; Baldock, T.E.; Birrien, F.; Callaghan, D.P.; Nielsen, P.; Beuzen, T.; Turner, I.L.; Blenkinsopp, C.E.; Ranasinghe, R. Laboratory investigation of the Bruun Rule and beach response to sea level rise. Coast. Eng. 2018. 10.1016/j.coastaleng.2018.03.003.

28. IBGE IBGE - Instituto Brasileiro de Geografia e Estatística. : http://www.sidra.ibge.gov.br/bda/orcfam/default.asp.

29. IBGE, I.B. de G. e E. Gross Domestic Product - GPD. Prod. Interno Bruto - PIB 2018.

30. FEPAM Fundação Estadual de Proteção Ambiental Henrique Luiz Roessler - RS. FEPAM 2020.

31. Dias, R.A.; Maurício, G.N.; Bugoni, L. Birds of the Patos Lagoon Estuary and adjacent coastal waters, southern Brazil: species assemblages and conservation implications. Mar. Biol. Res. 2017. 10.1080/17451000.2016.1209525.

32. Gaspar, M.D.; DeBlasis, P.; Fish, S.K.; Fish, P.R. Sambaqui (Shell Mound) Societies of Coastal Brazil. In The Handbook of South American Archaeology; 2008. 10.1007/978-0-387-74907-5_18.

33. Ribeiro, P.A.M.; Pestana, M.B.; Penha, M.A.P.; Calippo, F.R. Levantamentos Arqueológicos na Porção Central da Planície Costeira do Rio Grande do Sul, Brasil. Rev. Arqueol. 2004. 10.24885/sab.v17i1.194.

34. Geological Survey of Brazil, C. Sistema de Informações Geográficas da Mineração (SIGMINE) Available online: https://www.gov.br/anm/pt-br/assuntos/acesso-a-sistemas/sistema-de-informacoes-geograficas-da-mineracao-sigmine (accessed on Dec 22, 2020).

35. CNSA, N.R. of A.S. Georeferenced Archaeological Sites Available online: http://portal.iphan.gov.br/cna/pagina/detalhes/1227 (accessed on Dec 21, 2020).

36. FUNAI, N.I.F. Fundação Nacional do Índio Available online: http://www.funai.gov.br/index.php/shape (accessed on Feb 1, 2020).

37. MapBiomas Project MapBiomas - Collection 5.0 of Brazilian Land Cover \& Use Map Series Available online: https://mapbiomas.org/en (accessed on Jan 2, 2021).

38. Dillenburg, S.R.; Hesp, P.A. Geology and Geomorphology of Holocene Coastal Barriers of Brazil; Springer.; Heidelberg: Verlag, Berlin, 2009; ISBN 978-3-540-44771-9.

39. Asmus, M.L. Coastal Plain and Patos Lagoon. In Subtropical Convergence Environments; 1997. 10.1007/978-3-642-60467-6_3.

40. Perillo, G.M.E.; Piccolo, M.C.; Pino-Quivira, M. Estuaries of South America; Berlin, S., Ed.; Springer Berlin Heidelberg: Berlin, Heidelberg, 1999; ISBN 978-3-642-64269-2 978-3-642-60131-6. 10.1007/978-3-642-60131-6.

41. Dillenburg, S.R.; Barboza, E.G.; Tomazelli, L.J.; Hesp, P.A.; Clerot, L.C.P.; Ayup-Zouain, R.N. The holocene coastal barriers of Rio Grande do Sul. Lect. Notes Earth Sci. 2009. 10.1007/978-3-540-44771-9_3.

42. Calliari, L.J.; Toldo, E.E. Ocean Beaches of Rio Grande do Sul. In Brazilian Beach Systems; Short, A.D., Klein, A.H. da F., Eds.; Springer International Publishing: Cham, 2016; Vol. 17, pp. 507-541 ISBN 978-3-319-30392-5 978-3-319-30394-9. 10.1007/978-3-319-30394-9_18.

43. Tomazelli, L.J.; Villwock, J.A.; Dillenburg, S.R.; Bachi, F.A.; Dehnhardt, B.A. Significance of present-day coastal erosion and marine transgression, Rio Grande do Sul, southern Brazil. An. Acad Bras Ciênc 1998, 70, 221-229.

44. Calliari, L.J.; Winterwerp, J.C.; Fernandes, E.; Cuchiara, D.; Vinzon, S.B.; Sperle, M.; Holland, K.T. Fine grain sediment transport and deposition in the Patos Lagoon-Cassino beach sedimentary system. Cont. Shelf Res. 2009, 29, 515-529. 10.1016/j.csr.2008.09.019.

45. Andrade, M.M.; Toldo, E.E.; Nunes, J.C.R. Tidal and subtidal oscillations in a shallow water system in southern Brazil. Brazilian J. Oceanogr. 2018, 66, 245-254. 10.1590/s1679-87592018017406603.

46. Romeu, M.A.R.; Fontoura, J.A.S.; Melo, E. Typical scenarios of wave regimes off Rio Grande do Sul, Southern Brazil. J. Coast. 
Res. 2015. 10.2112/JCOASTRES-D-12-00085.1.

47. Machado, A.A.; Calliari, L.J.; Melo, E.; Klein, A.H.F. Historical assessment of extreme coastal sea state conditions in southern Brazil and their relation to erosion episodes. J. Aquat. Sci. 2010, 5, 277-286.

48. Guimarães, P. V.; Farina, L.; Toldo Jr., E.E. Analysis of extreme wave events on the southern coast of Brazil. Nat. Hazards Earth Syst. Sci. 2014, 14, 3195-3205. 10.5194/nhess-14-3195-2014.

49. Barletta, R. do C.; Calliari, L.J. Determinação da Intensidade das Tempestades que atuam no Litoral do Rio Grande do Sul, Brasil. Pesqui. em Geociências 2001. 10.22456/1807-9806.20276.

50. Tomazelli, L.; Villwock, J. Considerações Sobre o Ambiente Praial e a Deriva Litorânea de Sedimentos ao Longo do Litoral Norte do Rio Grande do Sul, Brasil. Pesqui. em Geociências 1992. 10.22456/1807-9806.21318.

51. Toldo Jr., E.; Dillenburg, S.; Almeida, L.; Tabajara, L.; Martins, R.; Cunha, L. Parâmetros Morfodinâmicos da Praia de Imbé, RS. Pesqui. em Geociências 1993. 10.22456/1807-9806.21279.

52. da Motta, L.M.; Toldo, E.E.; de Sá, L.E.; de Almeida, B.; Nunes, J.C. Sandy sediment budget of the midcoast of Rio Grande do Sul, Brazil. J. Mar. Res. 2015, 73, 49-69. 10.1357/002224015815848839.

53. Lima, S.F.; Almeida, L.E.; Toldo Jr., E. Estimativa da Capacidade de Transporte Longitudinal de Sedimentos a partir de Dados de Ondas para a Costa do Rio Grande do Sul. Pesqui. em Geociências 2001. 10.22456/1807-9806.20272.

54. Köppen, W. Das geographische System der Klimate; Allgemeine Klimalehre; Borntraeger, 1936;

55. Grimm, A.M. Variabilidade interanual do clima no Brasil. In Tempo e clima no Brasil; Cavalcanti, I.F.A., Ed.; Oficina de Textos: São Paulo, SP, Brasil, 2009 ISBN 978-85-86238-92-5.

56. Alvares, C.A.; Stape, J.L.; Sentelhas, P.C.; de Moraes Gonçalves, J.L.; Sparovek, G. Köppen's climate classification map for Brazil. Meteorol. Zeitschrift 2013, 22, 711-728. 10.1127/0941-2948/2013/0507.

57. Tomazelli, L. O Regime dos Ventos e a Taxa de Migração das Dunas Eólicas Costeiras do Rio Grande do Sul, Brasil. Pesqui. em Geociências 1993. 10.22456/1807-9806.21278.

58. Murray, N.J.; Phinn, S.R.; DeWitt, M.; Ferrari, R.; Johnston, R.; Lyons, M.B.; Clinton, N.; Thau, D.; Fuller, R.A. The global distribution and trajectory of tidal flats. Nature 2019. 10.1038/s41586-018-0805-8.

59. Jaxa ALOS Global Digital Surface Model “ALOS World 3D - 30m” (AW3D30) Available online: http://www.eorc.jaxa.jp/ALOS/en/aw3d30/.

60. Santillan, J.R.; Makinano-Santillan, M. Vertical accuracy assessment of 30-M resolution ALOS, ASTER, and SRTM global DEMS over Northeastern Mindanao, Philippines. In Proceedings of the International Archives of the Photogrammetry, Remote Sensing and Spatial Information Sciences - ISPRS Archives; 2016. 10.5194/isprsarchives-XLI-B4-149-2016.

61. Muehe, D. Panorama da Erosão Costeira no Brasil; Ministério do Meio Ambiente, 2018; ISBN 978-85-7738-394-8.

62. Absalonsen, L.; Elírio, T.J. A Influência da Inflexão Costeira na Variabilidade da Linha de Praia em Mostardas - RS. Pesqui. em Geociências 2007. 10.22456/1807-9806.19457.

63. Leal, K.B.; de Oliveira, U.R.; de Almeida Espinoza, J.M. Beach dune limit variation on Mostardense, Mar Grosso, Cassino and Barra do Chuí beaches, in the south of Brazil between 2003-2015. Quat. Environ. Geosci. 2018.

64. Simões, R.S.; De Oliveira, U.R. Monitoramento mensal da linha de costa no \{Balneário\} \{Mostardense $\}$ - $\{$ RS $\}$ entre 2016/2017 utilizando dados de $\{$ VANT\}. Quat. Environ. Geosci. 2020, 11. 10.5380/abequa.v11i1.65729.

65. Stive, M.J.F.; Aarninkhof, S.G.J.; Hamm, L.; Hanson, H.; Larson, M.; Wijnberg, K.M.; Nicholls, R.J.; Capobianco, M. Variability of shore and shoreline evolution. Coast. Eng. 2002, 47, 211-235. 10.1016/S0378-3839(02)00126-6.

66. Esteves, L.S.; Williams, J.J.; Dillenburg, S.R. Seasonal and Interannual Influences on the Patterns of Shoreline Changes in Rio Grande do Sul, Southern Brazil. J. Coast. Res. 2006, 225, 1076-1093. 10.2112/04-0227R.1.

67. Lélis, R.J.F.; Calliari, L.J. Historical Shoreline Changes Near Lagoonal and River Stabilized Inlets in Rio Grande do Sul State, Southern Brazil. J. Coast. Res. 2006, 301-305.

68. Alburquerque, M. da G. Análise espaço-temporal das causas da variabilidade da linha de costa e erosão na praia do Hermenegildo, RS, Federal University of Rio Grande do Sul: Porto Alegre, RS - Brazil, 2013. 
69. Vilibic, I.; Monserrat, S.; Rabinovich, A. (Eds. . Meteorological tsunamis: the u.s. east coast and other coastal regions; Ivica, V., Monserrat, S., Rabinovich, A.B., Eds.; 1st editio.; Springer: New York, 2014; ISBN 978-3-319-12711-8 978-3-319-12712-5.

70. Guimarães, P.V.; Farina, L.; Toldo, E.; Diaz-Hernandez, G.; Akhmatskaya, E. Numerical simulation of extreme wave runup during storm events in Tramandaí Beach, Rio Grande do Sul, Brazil. Coast. Eng. 2015, 95, 171-180. 10.1016/j.coastaleng.2014.10.008.

71. Parise, C.K.; Calliari, L.J.; Krusche, N. Extreme storm surges in the south of Brazil: atmospheric conditions and shore erosion. Brazilian J. Oceanogr. 2009, 57, 175-188. 10.1590/S1679-87592009000300002.

72. Leal-Alves, D.C.; Weschenfelder, J.; Albuquerque, M. da G.; Espinoza, J.M. de A.; Ferreira-Cravo, M.; Almeida, L.P.M. de Digital elevation model generation using UAV-SfM photogrammetry techniques to map sea-level rise scenarios at Cassino Beach, Brazil. SN Appl. Sci. 2020. 10.1007/s42452-020-03936-z.

73. Figueiredo, S.A.D.E. External forcing and internal controls on coastal response to climate change at Rio Grande do Sul, southern Brazil. PhD, Univ. Sydney 2011, 164.

74. Figueiredo, S.A. de; Goulart, E.S.; Calliari, L.J. Effects of closure depth changes on coastal response to sea level rise: Insights from model experiments in southern Brazil. Geomorphology 2020. 10.1016/j.geomorph.2019.106935.

75. Piazza Forgiarini, A.P.; Amaral de Figueiredo, S.; Calliari, L.J.; Goulart, E.S.; Marques, W.; Trombetta, T.B.; Oleinik, P.H.; Guimarães, R.C.; Arigony-Neto, J.; Cabral Salame, C. Quantifying the geomorphologic and urbanization influence on coastal retreat under sea level rise. Estuar. Coast. Shelf Sci. 2019. 10.1016/j.ecss.2019.106437.

76. Figueiredo, S.A. de; Calliari, L.J.; Machado, A.A. Modelling the effects of sea-level rise and sediment budget in coastal retreat at Hermenegildo Beach, Southern Brazil. Brazilian J. Oceanogr. 2018, 66, 210-219. 10.1590/s1679-87592018009806602.

77. IPCC Working Group 1 IPCC Fifth Assessment Report (AR5) - The physical science basis. IPCC 2014. 10.1017/CBO9781107415324.004. 